\title{
PENAL WELFARE AND THE NEW HUMAN TRAFFICKING INTERVENTION COURTS
}

\author{
Aya Gruber* \\ Amy J. Cohen* \\ Kate Mogulescu $^{* * *+}$
}

\begin{abstract}
In the fall of 2013, New York State's Chief Judge, Jonathan Lippman, announced a "revolutionary" statewide initiative to create Human Trafficking Intervention Courts (HTICs). The initiative occurred amidst a burgeoning consensus that prostitution is human trafficking and women who engage in prostitution are largely victims of exploitation and violence. Given the HTICs' ambition to, in Lippman's words, "eradicate the epidemic of human trafficking," and the convergent view of prostitution as trafficking, one might think the HTICs are courts that prosecute traffickers, where victim-witnesses enjoy special protections. In fact, the HTICs are criminal diversion courts where mostly female defendants are prosecuted for prostitution offenses but offered mandated services in lieu of criminal conviction and jail. The HTICs are thus a puzzle. Why have so many commentators heralded them as the model approach to prostitution/trafficking when they involve the arrest, prosecution, and even incarceration of prostitution defendants, who are presumed to be victims? A key piece of this puzzle is a phenomenon we call "penal welfare," that is, states' growing practice of using criminal courts to provide social services and benefits. In an era in which "mass incarceration" is a familiar term and tough-on-crime and broken windows ideologies are falling into disfavor, penal welfare enables entrenched institutions of criminal law to continue to function despite a growing crisis in public confidence. Based on a qualitative empirical study of the HTICs, we caution that because of their welfarist bent, the courts may sustain arrests and prosecutions of the presumptively victimized women they seek to protect, stunt the development of alternate forms of assistance and resources, and reinforce stigmatizing ideologies and discourses.
\end{abstract}

\footnotetext{
* Professor of Law, University of Colorado Law School.

** Professor of Law, Ohio State University School of Law.

*** Founder and Supervising Attorney of the Exploitation Intervention Project at the Legal Aid Society of New York; J.D. Yale Law School, 2003.

+ We thank Leigh Brady and Steven Broadley for transcribing interviews and Jessica Pingleton, Erika Kuhl, Kiki Council, and Leigh Brady for research assistance. We are especially grateful to all professionals who work in the courts for so generously sharing their experiences. We hope this Article honors the memory of Assistant District Attorney Kim Affronti whose frank and compassionate insights pepper our analysis and whose commitment to the individuals coming through the HTICs leaves a strong legacy.
} 
I. From Broken WINDOWS to HuMAN TrafFickinG.............1339

A. Prostitution as a Public-Order Offense........................1339

B. Prostitution as Domestic Violence ..............................1343

C. Prostitution as Human Trafficking ..............................1350

II. The HuMAN TRafFicking InTERvENTION COURTS..............1356

A. The Practice Prior to the Human Trafficking

Intervention Courts.

B. The Practice in Human Trafficking

Intervention Court

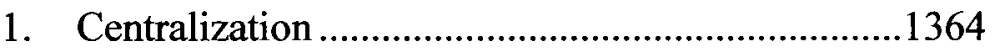

2. Judicial Style ........................................................1365

3. Services ...................................................................1366

4. Defendants with Records or Multiple

Charges

5. Evidence of Trafficking ......................................1375

III. TowaRD A PENAL WELfaRE SYSTEM .................................1378

A. The Limits of Reform from Within:

Decarceration and Procedural Justice ........................1379

1. Decarceration .......................................................1379

2. Procedural Justice..................................................1381

B. Sustaining Criminalization: From Public

Order to Penal Welfare

C. Sex Exceptionalism and Limitations

of the HTIC Model for Broader

Criminal Reform.

CONCLUSION

\section{INTRODUCTION}

Prostitution has long been culturally and politically divisive. At different moments in U.S. history, activists and policymakers have debated whether prostitution should be condemned as immoral behavior, a public health problem, and a community nuisance, or accepted (or at least tolerated) as sexual liberation, personal choice of employment, or just a fact of life. Today, as the issue of human trafficking occupies a continually greater space in public discourse, we are witnessing a renewed ideological divide: On one side are those who believe that commercial sex is work and that the state should regulate it through noncriminal means to reduce harm and improve the material well-being 
of sellers (the sex-work position). On the other side are those who believe that all commercial sex is human trafficking and that the state should prioritize dismantling the institution of prostitution, primarily by criminal enforcement against buyers and promoters (the new abolitionist or neoabolitionist position). ${ }^{1}$

This new "sex war," like its predecessor, is heated, ${ }^{2}$ and it is currently playing out on the local, national, and international stage. For example, in July 2015, a version of Amnesty International's "Draft Policy on Sex

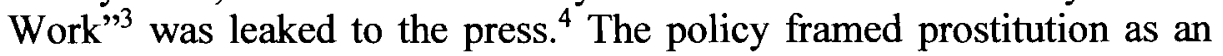
issue of international human rights and called on states to adopt programs to decriminalize, though not legalize, prostitution and take harmreduction measures, such as adopting occupational safety and health standards. ${ }^{5}$ The report provoked the ire of anti-trafficking groups, such as the Coalition Against Trafficking in Women (CATW), who along with religious and civic organizations and a string of Hollywood celebrities, ${ }^{6}$ vigorously condemned the policy as enabling human trafficking and launched a campaign to pressure the organization not to adopt it. ${ }^{7}$ The group circulated a sign-on letter that further excoriated Amnesty for

1. Anti-prostitution activists have sought to appropriate the anti-slavery term to describe their fight against human trafficking and commercial sex. For example, the New York "new abolitionist" website proclaims: "When people think of abolitionist leaders in New York State, the names of icons like Frederick Douglass, Harriet Tubman, Sojourner Truth, Henry Ward Beecher, and Elizabeth Cady Stanton come to mind. ... But New York State has a new generation of 21st century abolitionists, women and men committed to ending human trafficking here in New York State and everywhere." The Story, N.Y.'s NEw ABOLITIONISTS (2015), http://www.new yorksnewabolitionists.com/.

2. For a discussion of the original sex wars, see infra Section I.C.

3. AMnesty InT'L, 2015 ICM Circular: Draft Policy on Sex Work (2015), http://tasmaniantimes.com/images/uploads/Circular_18_Draft_Policy_on_Sex_Work_final.pdf.

4. Doreen Carvajal, Amnesty International Considers Pushing for Decriminalization of Prostitution, N.Y. TIMES (July 31, 2015), http://www.nytimes.com/2015/08/01/world/europe/ amnesty-international-weighs-decriminalization-of-prostitution.html.

5. AMNESTY INT'L, supra note 3, at 7, 10-11.

6. Celebrities included Lena Dunham, who was herself the subject of condemnation as a sex offender after she revealed in her biography an arguably sexual episode involving her sister. See Seth Abramovitch, Lena Dunham, Kate Winslet Face off with Amnesty International over Sex-Trade Debate, HollYwOOD REP. (July 27, 2015, 1:57 PM), http://www.hollywoodreporter. com/news/lena-dunham-kate-winslet-face-811287; Judith Levine, Lena Dunham Wasn't a Pedophile, and Neither Were You, Bos. REv. (Nov. 10, 2014), https://bostonreview.net/blog/judi th-levine-lena-dunham-sister-sexual-abuse.

7. See Letter from Magdy Abdel-Hamid, Egyptian Ass'n for Cmty. Participant Enhancement, et al., to Salil Shetty, Sec'y Gen., Amnesty Int'l, et al. 3 (July 22, 2015) [hereinafter Letter to Amnesty Int'i], http://catwinternational.org/Content/Images/Article/617/attachment.pdf ("Amnesty's reputation in upholding human rights for every individual would be severely and irreparably tarnished if it adopts a policy that sides with buyers of sex, pimps and other exploiters rather than with the exploited."). 
taking the side of "Caucasian men" against "[d]isenfranchised women of color."8

The rift runs deep, but there is one thing on which both sides agree: Those engaged in commercial sex are not criminals. The sex-work position holds that they are often victims of oppressive labor conditions (including individual and systemic violence) and therefore deserve safe and remunerative conditions of work. The neo-abolitionist position holds that commercial sex is inherently coercive, and thus anyone engaged in selling sex is a victim of human trafficking. For both camps, prostitution/trafficking intervention should not involve the state arresting, prosecuting, or incarcerating women.

In the fall of 2013, in the midst of this debate, New York State's Chief Judge, Jonathan Lippman, announced a "revolutionary" statewide initiative: New York would implement Human Trafficking Intervention Courts (HTICs) to "eradicate the epidemic of human trafficking." "Given this ambition and the convergent view that those engaging in prostitution are victims, one might think that the HTICs are courts that prosecute traffickers, where victim-witnesses enjoy special protections, or perhaps that the HTICs aid trafficked women in pursuing assistance. In fact, the HTICs are criminal diversion courts in which mostly female defendants are prosecuted for prostitution offenses. ${ }^{10}$ These presumed victims' presence in court is compulsory. ${ }^{11}$ Their participation in treatment and services is mandated under pain of prosecution. ${ }^{12}$ Conviction and jail are real possibilities. ${ }^{13}$

The HTICs are thus a puzzle. Why have so many commentators, including neo-abolitionists, proclaimed them as the model approach to prostitution/trafficking when they involve the arrest, prosecution, and even incarceration of prostitution defendants, who are presumed to be victims? The majority of these defendants are, in fact, poor women of color, the precise group whose interests trafficking activists claim to have at the center of their agenda. ${ }^{14}$

8. Id.

9. Jonathan Lippman, Announcement of New York's Human Trafficking Intervention Initiative, CTR. FOR CT. INTER VENTION (Sept. 25, 2013), http://www.courtinnovation.org/research/ announcement-new-yorks-human-trafficking-intervention-initiative.

10. Michelle Chen, Why Do Sex-Work Diversion Programs Fail?, NATION (Sept. 25, 2015), http://www.thenation.com/article/why-do-sex-work-diversion-programs-fail/.

11. Id.

12. Id.

13. Id.

14. From 2010 to 2014, 87.4\% of the individuals arrested in New York City for Prostitution, P.L. $\S 230.00$, or Loitering for the Purpose of Engaging in a Prostitution Offense, P.L. $§ 240.37$, the two charges that merit inclusion in the HTICs, were identified by the arresting agency as Black, Hispanic, or Asian. N.Y. Div. of Criminal Justice Servs. Prostitution Loitering for 
A key piece of this puzzle is a phenomenon we call "penal welfare," that is, states' growing practice of providing social benefits through criminal court. ${ }^{15}$ The Chief Judge distinguished HTIC process from the status quo "pattern of shuffling trafficking victims through our criminal courtrooms without addressing the underlying reasons why they are there in the first place." 16 In the HTICs, he explained, defendants charged with prostitution receive "services that will assist them in pursuing productive lives rather than sending them right back into the grip of their abusers." 17 Those who comply with service mandates have "the opportunity to receive non-criminal dispositions or dismissal." 18 Thus, although one might think the obvious consequence of re-envisioning prostitution defendants as victims would be less criminal intervention, the HTIC model suggests greater intervention in prostitution defendants' lives. It does so by repackaging criminal intervention as welfare and the arrest and prosecution of presumed victims as a minimal cost of eradicating trafficking, if not a net benefit to arrestees.

The story of this reform from within is unsurprisingly complex. The HTICs' new identity as a welfare institution for subordinated women inevitably conflicts with traditional criminal court objectives of punishing and deterring crime and conflicts with procedures that reserve harshest treatment for those who repeat offend, fail to appear, and violate court mandates. ${ }^{19}$ We thus examine not only the HTICs' complex and contradictory internal structure but also their relationship to prevailing criminological and court reform trends and current views of gender and sexuality. Ultimately, we caution that the HTICs and the rhetoric

Prostitution Arrest Dispos NYC Since 1990 Computerized Oracle File (Jan. 20, 2015). In that same period, $79.9 \%$ were identified as female. Id. However, the gender assigned by the arresting agency does not always comport with an individual's actual gender identity. See MAKE THE ROAD N.Y., Transgressive Policing: Police ABUSE of LGBTQ Communities of COLOR IN JACKSON HEIGHTS 11(2012), http://www.maketheroad.org/pix_reports/MRNY_Transgressive_Policing_F ull_Report 10.23.12B.pdf. This percentage would be significantly higher were transgender women identified as female rather than male in arrest data.

15. The term penal welfare appears in legal and sociological literature in a number of contexts. Perhaps the most well-known use of the term is David Garland's description of penalwelfarism. David Garland, The Culture of ConTrol: Crime and Social Order in CONTEMPORARY SOCIETY 38 (2001). In short, Garland contrasts penal welfarism, which embraces rehabilitation, indeterminate sentencing, expertise, diagnosis, and the like, with more classic penal ideologies like retributivism and the principle of legality. See id. at 38-39. Although our use of penal welfare overlaps with the distinctions explored by Garland, we specifically intend to highlight how criminal courts today administer "ordinary" welfare, including basic services, material goods, and other social-safety net items. See infra Section III.B.

16. See Lippman, supra note 9.

17. 1 .

18. Id.

19. See infra Subsection II.B.4. 
underlying them, despite (or more likely because of) their welfarist bent, may sustain the criminalization of sellers of sex, stunt the development of programs that provide material assistance outside the courts, and reinforce ideologies and discourses that stigmatize commercial sex. ${ }^{20}$ But regardless of one's position on sex work versus abolition, criminal justice actors and advocates should have a clear-eyed view of the promises and perils of the HTICs before declaring them an exemplar to replicate throughout the nation..$^{21}$ If not, the force of the anti-trafficking movement, sympathy for women victims, and moral criticisms of paid sex may herald rapid reforms which, decades later, prove misguided and near impossible to reverse. ${ }^{22}$

Our analysis derives from a range of data, including debates and discussion on the HTIC initiative at city council hearings, court records of specific cases, legislation, and statistics, as well as court observations in June 2014, and extensive interviews with key stakeholders in four New York City borough courts (Manhattan, Queens, Brooklyn, and the Bronx). ${ }^{23}$ Co-authors Aya Gruber and Amy J. Cohen interviewed the HTIC presiding judge and HTIC defense attorneys in each borough, HTIC prosecutors in Queens, Brooklyn, and the Bronx, social workers, advocates, and staff members at the Center for Court Innovation-the public-private think tank that helped develop the HTICs. Our analysis is also extensively informed by co-author Kate Mogulescu who, as founder and supervising attorney of the Exploitation Intervention Project at the Legal Aid Society of New York, has focused her practice on the representation of prostitution defendants since 2010 and currently supervises a team of attorneys who practice daily in the HTICs. ${ }^{24}$ Our assessment is necessarily preliminary, given that the HTICs have only operated since the fall of 2013.

This Article proceeds in three Parts. First, it offers a history of the legal and political terrain upon which the HTICs were constructed, emphasizing the philosophical shift from viewing prostitution defendants as quality-of-life offenders to viewing them as victims of domestic or

20. See infra Sections III.B, III.C.

21. See, e.g., Lippman, supra note 9 (calling the courts "a trail blazer").

22. See, e.g., Press Release, Cook Cty. State Attorney's Office, Cook County Unveils New Prostitution and Trafficking Intervention Court (May 29, 2015), http:/www.statesattorney.org/ press_ProstitutionAndTraffickingInterventionCourt.html (noting that " $[\mathrm{t}]$ he program was developed with technical assistance from the Center for Court Innovation in New York and modeled after a similar successful program in Manhattan, New York").

23. Two of our interviewees wished to remain anonymous. Staten Island, although one of the five boroughs that make up New York City, does not have a large enough number of prostitution-related arrests to justify a regular HTIC calendar.

24. See Legal Aid Expands Program for Trafficking Victims, LEGAL AID SOC'Y (Mar. 22, 2013), http://www.legalaid.org/en/mediaandpublicinformation/inthenews/legalaidexpandsprogra mfortraffickingvictims.aspx. 
gender violence and sex trafficking. Second, the Article engages in a description of the courts, exposing the various dissonances inherent in prosecuting "victims" and merging punishment and welfare. Finally, it turns to a critical balancing of the benefits and drawbacks of the HTIC model. While commending reform efforts to reduce incarceration and provide assistance, we nonetheless sound some cautionary notes about the limits of reform from within, the connection of the HTIC model to continued arrest and prosecution of prostitution suspects, and the tenuous nature of a decarceration or welfare program specifically linked to (female) defendants' status as victims of the commercial sex industry.

\section{From Broken Windows to Human TrafFicking}

\section{A. Prostitution as a Public-Order Offense}

The offense of prostitution has a long and complex history in this country, and outlining that history is well beyond the scope of this Article. In the seventeenth, eighteenth, and nineteenth centuries, prostitution offenses fell into the category of moral offenses such as vagrancy, drunkenness, and disorderly conduct. ${ }^{25}$ Shades of this moral paradigm exist in New York City today, with prostitution still classified as a "vice" offense and the existence of regulations like the "Bawdy House Law," which permits tenants and neighbors to force landlords of a "bawdyhouse, or house or place of assignation for lewd persons, or for purposes of prostitution" to evict their degenerate tenants. ${ }^{26}$ But by the latter part of the twentieth century, prostitution prosecution was increasingly unlikely to be justified on the ground of protecting society from libertine degradation.

Fast-forward to the 1980s and 90s: A new moral ethos-grounded in ideas of social disorder and economic stability - prompted an explosion of street policing and misdemeanor prosecution, including the policing and prosecution of prostitution. Throughout the 1980s, New York City became widely known as a city out of control, and in 1990, Time Magazine declared it a "rotting Big Apple," emphasizing the point visually by the "I Love NY" heart breaking. ${ }^{27}$ Times Square conjured up

25. See Vern Bullough \& Bonnie Bullough, Women and Prostttution: A SOCIAL HISTORY 277, $280-82$ (Prometheus Books rev. ed., 1987) (1978).

26. N.Y. REAL PROP. ACTS. $\$ 715$ (1) (McKinney 2016). Interestingly, in 2013, just months before the roll out of the HTICs, New York passed legislation called the "Bawdy House Bill" that allows criminal prosecutors to aid in and expedite such eviction proceedings. Press Release, Jeffrey D. Klein, Senator, N.Y. State Senate, Senate Passes Klein Bill Empowering D.A.'s to Evict Drug Dealers and Violent Criminals from Neighborhood Homes (May 7, 2013), http://www. nysenate.gov/press-release/senate-passes-klein-bill-empowering-das-evict-drug-dealers-and-viol ent-criminals-neigh.

27. See Joelle Attinger, The Decline of New York, Time, Sept. 17, 1990, at 36, 37-39. 
images of seedy sex shops and peep shows, and many considered the subway a war zone in which thugs terrorized innocent passengers. ${ }^{28}$ Against this backdrop, former District Attorney Rudolph Giuliani ran for mayor on a tough-on-crime platform. ${ }^{29}$

Under Mayor Giuliani, New York pioneered an approach to policing that built on psychologist George Kelling and criminologist James Q. Wilson's influential 1982 article, Broken Windows. ${ }^{30}$ The upshot was that visible disorder had a strong causal link to violent crime, such that police could effectively reduce serious criminal activity by targeting crimes that created a perception of community decay. ${ }^{31}$ Specifically, the authors focused on "disreputable or obstreperous or unpredictable people" like "panhandlers, drunks, addicts, rowdy teenagers, prostitutes, loiterers,

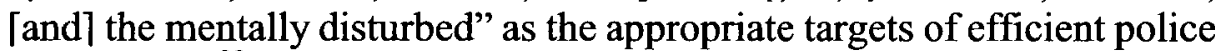
intervention. ${ }^{32}$

As this quotation suggests, in the new public-order paradigm, prostitutes were considered both exemplary and unexceptional low-level offenders, akin to drunks, turnstile jumpers, and vagrants. William Bratton, Giuliani's first police commissioner, explained that he embraced broken windows theory through personal experience as an officer in Boston, where inner-city residents told him they worried most about "prostitution and graffiti." 33 Indeed, for Bratton, targeting misdemeanants and other low-level offenders was both a means to the end of preventing more serious crime and a way to put an "emphasis on

28. See Robert Victor Wolf, New Strategies for an Old Profession: A Court and a Community Combat a Streetwalking Epidemic, 22 JUST. SYS. J. 347, 347-48 (2001); Joseph Berger, Goetz Case: Commentary on Nature of Urban Life, N.Y. TIMES, June 18, 1987, at B6 (asserting that Goetz's acquittal reflected "the nervousness that courses through much of urban experience, from riding the subway at night to walking a darkened street"); William Glaberson, Chilled by Violence, New Yorkers Are Questioning Life in Their City, N.Y. TiMES, Sept. 16, 1990, at 40.

29. He ran against New York City's first black mayor, David Dinkins. Tocid S. Purdum, The 1993 Elections: Mayor; Guiliani Ousts Dinkins by a Thin Margin; Whitman Is an Upset Winner over Florio, N.Y. TIMES (Nov. 3, 1993), http://www.nytimes.com/1993/11/03/nyregion/ 1993-elections-mayor-giuliani-ousts-dinkins-thin-margin-whitman-upset-winner.html. Giuliani vowed to clean up the streets, capitalizing on the racial tensions running high in the wake of riots and sectarian clashes, and narrowly won the election in a polarized vote. See Todd S. Purdum, Election of Giuliani Reveals a Delicate Balance, N.Y. TIMES (Nov. 7, 1993), http://www.nytimes. com/1993/1 1/07/nyregion/political-memo-election-of-giuliani-reveals-a-delicate-balance.html.

30. George L. Kelling \& James Q. Wilson, Broken Windows: The Police and Neighborhood Safety, ATLANTIC (Mar. 1982), http://www.theatlantic.com/magazine/archive/1982/03/brokenwindows $/ 304465 /$.

31. See id.

32. Id.

33. Bruce Weber, James Q. Wilson Dies at 80; Originated 'Broken Windows' Policing Strategy, N.Y. TiMES (Mar. 2, 2012), http://www.nytimes.com/2012/03/03/nyregion/james-qwilson-dies-at-80-originated-broken-windows-policing-strategy.html. 
crimes committed against the community" for their own sake. ${ }^{34}$ Prostitution policing was expedient because it was an efficient way of reducing crime overall and retributively appropriate because prostitutes, like other obstreperous offenders, were in effect terrorizing the community. According to one commentator working to reform the New York criminal justice system:

While many people think of prostitution as a victimless crime, for the people who lived and worked in the area it was anything but. Neighborhood residents were afraid to let their children play outside not only because of the scantily clad women and their barely concealed sexual activity, but also because of the crack vials, used needles, and discarded condoms they left behind. ${ }^{35}$

For the most part, what emerged in the wake of community policing was the rise of what scholars call "mass misdemeanors" - a criminal law regime that left defendants marked with lengthy records of arrests and convictions, but not necessarily having suffered lengthy jail stints. ${ }^{36}$ For. many prostitution arrestees, this process involved appearing in arraignment court, pleading guilty to a misdemeanor or a violation immediately, and leaving the courtroom having been sentenced to a short jail sentence, or even time served, and no further required appearancesprompting many stakeholders to describe these cases as "disposable."37

There was, however, an early attempt to treat prostitution, and other public-order misdemeanors, in a nondisposable manner. In 1993, the New York court system in collaboration with the Center for Court Innovation (CCI), a public-private court-reform think tank, ${ }^{38}$ launched the Midtown Community Court (MCC). According to CCI:

Launched in 1993, the Midtown Community Court targets quality-of-life offenses, such as prostitution, illegal vending, graffiti, shoplifting, farebeating and vandalism. Typically in these cases, judges are forced to choose between a few days of jail time and nothing at all-sentences that fail to impress upon the victim, the community and the defendants that

34. Id.

35. Wolf, supra note 28 , at 348 .

36. See Issa Kohler-Hausmann, Managerial Justice and Mass Misdemeanors, 66 STAN. L. REv. 611,639 (2014) (observing how New York City misdemeanor courts sort, categorize, and mark individuals on the basis of their contacts with the system).

37. Public defender Abigail Swenstein explains that prostitution cases, like other misdemeanors, "are called 'dispos' because those are cases that are disposable." Interview with Abigail Swenstein, Attorney, Legal Aid Soc'y, in New York, N.Y. (June 23, 2014).

38. What We Do: Research, Operating Programs, Expert Assistance, CTR. FOR CT. INNOVATION, http://www.courtinnovation.org/what-we-do (last visited Mar. 13, 2016). 
these offenses are taken seriously. In contrast, the Midtown Community Court sentences low-level offenders to pay back the neighborhood through community service, while at the same time offering them help with problems that often underlie criminal behavior. ${ }^{39}$

MCC experimented with a dual approach to quality-of-life offenders that combined punishment, in the form of corrective community service, with self-help, in the form of social and pedagogical services. ${ }^{40}$ It embodied, in part, what New York City judicial officials call an accountability model. ${ }^{41}$ Sentences reflected offender culpability and made defendants "pay back" victims - in this case the community - by literally repairing broken windows through visible community restitution projects. ${ }^{42}$

When it came to prostitution, although reformers hoped mandated services would give women the tools to "leave the life," the overarching goal of the court was simply to achieve crime reduction and community stability in Midtown. ${ }^{43}$ To that end, MCC doled out sentences that, quite deliberately, made it difficult to continue to sell sex in Times Square. ${ }^{44}$ For example, the court often scheduled community service at night to make it harder for women "to walk the streets." ${ }^{45}$ MCC court reformers also boasted that their intensive service mandates (such as participation in health-education classes) created their own disincentives to arrest. ${ }^{46}$ They surmised that many prostitutes preferred a perfunctory system of minor convictions and short jail stints and, as a result, engaged in a form of self-deportation to boroughs with more hospitable legal regimes. ${ }^{47}$ The

39. Press Release, Groundswell, As New York City Struggles to Transform Its Juvenile Justice System, Court-Involved Youth Use Art as a Tool for Personal Transformation (May 29, 2015), http:/www.groundswell.nyc/sites/default/files/As\%20NYC\%20Transforms\%20Juvenile $\% 20$ Justice,\%20Court-Involved\%20Youth\%20Transform\%20their\%20Lives.pdf.

40. See id.

41. See generally Domestic Violence Comm., N.Y.C. Bar, ChoOsing Between Batterers education Program Model.s: Recommendations to the New York City DOMESTIC ViolenCE Criminal AND FAMILY COURTS (2004) (discussing an accountability model for DV offenses); Melissa Labriola et al., Court Responses to Batterer Programs NonCompliance: A National Survey, 94 JUdiCATURE 81, 82-84 (2010).

42. Midtown Community Court, CTR. FOR CT. INNOVATION, http://www.courtinnovation.o $\mathrm{rg} /$ project/midtown-community-court (last visited Sept. 21, 2016).

43. See Wolf, supra note 28 , at $351,353$.

44. Id. at $352-53$.

45. Id. at 352 .

46. See id. at $352-54$.

47. In MCC, repeat offenders were likely to receive incarceration terms significantly longer than in conventional courts. See MiChELE SVIRIDOFF ET AL., DisPENSING Justice LOCALLY: THE IMPLEMENTATION AND EFFECTS OF THE MIDTOWN COMMUNITY COURT 54-59 (2000). 
interventions did reduce prostitution arrests in Midtown. ${ }^{48}$ For many, the question of why Times Square prostitution receded was far less important than the fact of its decline. As one CCI official remarked, "It's impossible to know for certain how many prostitutes have been persuaded to quit the business altogether. But from the perspective of stakeholders in the Midtown community, it almost doesn't matter. What does matter is that visible signs of prostitution in the neighborhood have been dramatically reduced ....."49

In many ways, the community-court experiment continues to influence the HTICs today. Numerous participants involved in the HTICs offer the same basic critiques of "disposable" prostitution cases leveled by community-court advocates: that all too often prostitutes are arrested and prosecuted only to be given time served, without intensive services, counseling, and other disincentives to reoffend. ${ }^{50}$ At the same time, the HTICs have sharply distinguished their goals from the community court's rather modest aspirations to reduce the visibility of commercial sex. For example, in the community-court era, the founder of a vocal anti-. prostitution citizens group that worked closely with MCC explained that she only objected to prostitution when it occurred visibly in her neighborhood. ${ }^{51}$ In sharp contrast, the HTICs have been spurred by advocates and activists who see these courts as tools to directly reduce violence against women, if not combat a global slave trade in sex itself. $^{52}$ Judge Judy Kluger, the former Chief Judge of Policy and Planning for New York courts, who oversaw the rollout of the HTICs, put the point in no less ambitious terms: New York's trafficking intervention courts, she argued, "offer an unprecedented lifeline to many." 53

\section{B. Prostitution as Domestic Violence}

Relatively contemporaneous with the broken windows revolution, another significant reform program-domestic violence law reform-was sweeping U.S. courts. ${ }^{54}$ This program would come to shape the

48. Id. at 38 .

49. Wolf, supra note 28 , at 355 . Indeed, during the court's first year and a half of operation, prostitution arrests decreased by $56 \%$. SVIRIDOFF ET AL., supra note 47 , at 155 . Interviews with sex workers suggest that they were deterred by the demands of court appearances and community service. $I$ d. at 57.

50. See Interview with Abigail Swenstein, supra note 37.

51. Wolf, supra note 28 , at 356 .

52. See, e.g., Lippman, supra note 9.

53. Judy Harris Kluger, New York's Trafficking Courts Save Lives, N.Y. Dally News (Oct. $12, \quad 2014,4: 55$ AM), http://www.nydailynews.com/opinion/judy-harris-kluger-new-yorktrafficking-courts-save-lives-article-1.1970657.

54. See generally ElizABETH M. SCHNEIDER, BATTERED WOMEN FEMINIST LAWMAKING 3 10 (2000) (discussing the domestic violence reform movement). 
HTICs just as much as the community-court/public-order model. Indeed, numerous judges and policymakers have commented that they experience the current moment of anti-trafficking agitation as analogous to the early era of domestic violence activism when consciousness-raising around the issue began to produce both penal law and court reform. As Judge Toko Serita, who presides over the Queens County HTIC, explained: "I really equate people's reactions to trafficking victims who are in situations of intimate partner violence with their pimp/exploiter in some ways with where we were with domestic violence issues about 30 years ago." ${ }^{55}$ Or as State Assemblywoman and new-abolitionist Amy Paulin explained:

[T] he reason I have become the author of the [Trafficking Victims Protection and Justice Act ${ }^{56}$ and one of its champions is because of my work working with the advocates for domestic violence, and I began that work in 1993 and at the time in 1993, we were at about the same place in that issue as we are with this one. We did not have Integrated Domestic Violence Courts. . . . We were just at the cusp of . . a lot of change[] . ... ${ }^{57}$

Here, very briefly, is some of the history Judge Serita and Paulin are invoking. In the 1970s, second-wave feminists turned their attention to the problem of domestic violence. ${ }^{58}$ Feminists lobbied lawmakers for funding for shelters and services and for systemic reforms that would encourage police, prosecutors, and judges to treat domestic violence "like

55. Interview with Toko Serita, Presiding Judge, Queens Human Trafficking Intervention Court, in New York, N.Y. (June 24, 2014).

56. New York State Senator Paulin authored the Trafficking Victims Protection and Justice Act (TVPJA), which was passed by both houses of the New York State Legislature in March 2015, and was signed into law by New York's Governor in October 2015. See Press Release, Senator Andrew J. Lanza, Lanza \& Paulin Announce Passage of Historic Human Trafficking Bill in Both Houses of Legislature (Mar. 17, 2015), http:/www.nysenate.gov/press-release/lanzapaulin-announce-passage-historic-human-trafficking-bill-both-houses-legislature. Among other things, the TVPJA enhances penalties for trafficking offenses, creates additional crimes related to prostitution, and removes the word "prostitute" from the Penal Law, replacing it with the phrase "person for prostitution.” A.506, S.7, 2015-2016 Gen. Sess. (N.Y. 2015); Press Release, Senator Andrew J. Lanza, supra.

57. Oversight: How Do the Human Trafficking Intervention Courts Address the Needs of New York City's Runaway and Homeless Youth Population?: Hearing Before the Committee on Youth Services, 2010-2013 Sess. 88 (N.Y.C. Council 2013) [hereinafter Oversight Transcript] (statement of Amy Paulin, State Assemblywoman, N.Y. State Assembly) (footnoted added), http://legistar.council.nyc.gov/Legislation.aspx (search "T2013-6914" for the year 2013; then follow the "T2013-6914" hyperlink in the results; then follow the "Hearing Transcript" hyperlink in the Attachments row on the resulting webpage).

58. See Aya Gruber, The Feminist War on Crime, 92 Iowa L. REv. 741, 748-49 (2007). 
any other crime," rather than as a private family matter. ${ }^{59}$ In the $1980 \mathrm{~s}$, a powerful (but by no means uncontroversial) strand of the domestic violence reform movement began to recruit the institutions of criminal law. In 1983, President Ronald Reagan announced the formation of a task force to look into family violence, which was increasingly being touted as a public-health crisis. ${ }^{60}$ The task force's 1984 report characterizes domestic violence as a breakdown of family values and prescribes state intervention into the dysfunctional family, with the proviso that such intervention be exclusively criminal. ${ }^{61}$ It states, "The legal response to family violence must be guided primarily by the nature of the abusive act, not the relationship between the victim and the abuser." 62 This carceral view limned by the Reagan Administration received further traction from the 1984 publication of criminologist Lawrence Sherman's famous Minneapolis Domestic Violence Experiment, which found that arrest, as opposed to a warning or temporary separation, best reduced recidivism. ${ }^{63}$ Based on this research, domestic violence reformers endorsed proprosecution policies, encouraging separation, and legislatures began to. adopt rules for mandatory arrest. ${ }^{64}$

In the $1990 \mathrm{~s}$, domestic violence (DV) courts quickly followed the passage of new arrest laws. ${ }^{65}$ Specialized DV courts featured case consolidation in front of a trained judge, DV prosecution units, no-drop prosecution policies, victim advocates, and streamlined protection-order processes. ${ }^{66} \mathrm{DV}$ court reform also sounded in the broader problem-

59. Id. at $748-49,795$. For a discussion of this history, see generally SCHNEIDER, supra note 54 , at $38-42$.

60. See U.S. ATtORNEy General's TASK ForCE ON FAMILY ViolenCE, Final REPORT 75 (1984); Mary S. Hood \& Julie Kunce Field, Domestic Abuse Injunction Law and Practice: Will Michigan Ever Catch up to the Rest of the Country?, 73 MiCH. B.J. 902, 906 n.1 (1994) ("In 1985, Surgeon General C. Everett Koop told health professionals that domestic violence was a 'public health menace.'"); The History of Crime Victims' Rights in America, MD. CRIME VICTIMS' RES. CTR., http://www.mdcrimevictims.org/laws-and-policies/history-of-crime-victims-rights-in-ame rical (last visited May 16, 2016).

61. U.S. ATTORNEY GENERAL'S TASK FORCE ON FAMILY VIOLENCE, supra note 60, at 3-4.

62. Id. at 4. The report continues, "[t]he prosecutor and the judge, not the victim, determine whether the case is prosecuted or dismissed." Id. at 30 .

63. Lawrence W. Sherman \& Richard A. Berk, Police Found. Reports, The MINNEAPOLIS DOMESTIC VIOLENCE EXPERIMENT 6-7 (1984).

64. See Gruber, supra note 58, at 802. For tables listing states with mandatory arrest provisions as well as states with preferred arrest provisions, see David Hirschel et al., Domestic Violence and Mandatory Arrest Laws: To What Extent Do They Influence Police Arrest Decisions?, 98 J. CRIM. L. \& CRIMINOLOGY 255, 266-69 (2007).

65. Melissa labriola et al., Ctr. for Court innovation, a National Portrait of DOMESTIC VIOLENCE COURTS 1 (2009), https://www.ncjrs.gov/pdffiles1/nij/grants/229659.pdf.

66. See Gruber, supra note 58, at 747; G. Kristian Miccio, A House Divided: Mandatory Arrest, Domestic Violence, and the Conservatization of the Battered Women's Movement, 42 Hous. L. REv. 237, 265-66 (2005); Betsy Tsai, The Trend Toward Specialized Domestic Violence 
solving court movement. Recognizing DV as a recurrent problem, reformers integrated rehabilitation into the case process, and sentences for defendants typically included mandatory anger-management or domestic violence courses. ${ }^{67}$ As one early DV court explained, it aimed "to protect the abused partner and children, to hold the perpetrator accountable for violent behavior, [and] to stop that behavior and rehabilitate the perpetrator." ${ }^{\text {68 }}$ But despite this emphasis on rehabilitation, most if not all DV courts drew a clear distinction between victims and defendants: (Male) defendants are fully culpable autonomous criminals who should be harshly sanctioned, and (female) victims are innocent of any contribution to the violence and in extreme need of government protection. ${ }^{69}$ As Judge Leventhal, who presided over New York's first specialized DV court, made clear: his court was designed to "protect victims and punish the guilty."70

This bright line between victims and defendants did not hold in practice. First, many of the abuse victims appearing in DV court were not officially "innocent." They were simultaneously defendants in cases ranging from narcotics offenses to prostitution. ${ }^{71} \mathrm{DV}$ police calls sometimes ended up in dual arrests, the man for DV and the woman for

Courts: Improvements on an Effective Innovation, 68 FoRDHAM L. REV. 1285, 1300 (2000). Thus, what began as an exhortation to treat DV like other crimes ended up with a highly specialized court process. As one court reformer remarked, "Judges need to recognize at the outset that domestic violence cases differ from other crimes they are accustomed to seeing on the bench. Accordingly, their response must also differ." MARTHA WADE STEKETEE ET AL., NAT'L CTR. FOR StATE COURTS, IMPLEMENTING AN INTEGRATEd DOMESTIC VIOLENCE COURT: SySTEMIC CHANGE IN THE DisTRICT OF COLUMBIA 5 (2000).

67. The Colorado DV process, for example, involves extensive risk-assessment and treatment protocols. See David B. Harrison \& Timothy L. Johnson, The New Domestic Violence Treatment Standards for 2010, 39 COLO. LAW. 45, 46-51 (2010).

68. JAMES NOLAN JR., LEGAL ACCENTS, LEgal BORROWING: THE INTERNATIONAL PROBLEM-SOLVING COURT MOVEMENT 14 (2009) (alteration in original).

69. See Gruber; supra note 58, at 808-09. Indeed, in New York and elsewhere many activists argue that domestic abusers should be treated more punitively than nondomestic assailants. See Miccio, supra note 66, at 265-66.

70. NOLAN, supra note 68, at 15 . The court launched in Brooklyn in 1996 as a felony court but was soon to be followed by several misdemeanor courts. Domestic Violence Court, CTR. FOR COURT INNOVATION, http://www.courtinnovation.org/project/domestic-violence-courts (last visited May 16, 2016). Currently, there are approximately thirty-five DV courts operating in New York State. Id. Several other major cities developed specialized DV courts in the 1990s, including Miami and Washington, D.C., but the bulk of specialized DV courts were developed in the 2000 s. See LABRIOLA ET AL., supra note 65, at 2.

71. See Veronica L. Zoltowski, Note, Zero Tolerance Policies: Fighting Drugs or Punishing Domestic Violence Victims?, 37 NEW ENG. L. REv. 1231, 1241-43, 1245-46, 1248 (2003). 
child abuse or neglect. ${ }^{72}$ Second, many women were reluctant to aid DAs in prosecuting their intimate partners ${ }^{73}$ or even to separate from them, further complicating the distinction between the victim and her offender.

What emerged was a complex and often contradictory legal regime. When women chose not to prosecute, prosecutors and anti-violence advocates tried to maintain their status as victims by arguing their decisions were not autonomous but compelled by the abuser-what they called, in shorthand, "coercive control." 74 Based on this theory, antiviolence advocates succeeded in implementing a legal structure that urged prosecutors to compel reluctant victims to cooperate or to proceed to trial without victim testimony (for example, on the basis of prior statements). ${ }^{75}$ At the same time, however, when women who experienced domestic abuse made other "bad choices" such as committing crimes (that may also reflect experiences of violence and abuse), they were often treated as fully autonomous and culpable agents. ${ }^{76}$ In other words, in jurisdictions throughout the United States, including New York, coercive control licensed prosecutors to override uncooperative victims. Yet the law made no provision for defense attorneys to invoke coercive control as a defense to abused women's own criminal liability in other contexts.

In New York City, all this was about to change, at least when it came to prostitution charges. Recall that throughout the 1990s, the justice system in New York regarded prostitution as a mass misdemeanor or community offense, and the women involved as responsible, albeit petty, offenders. ${ }^{77}$ By contrast, it treated domestic violence as a serious crime, and the women involved as coercively controlled victims. In 2002, a Queens court judge, in a series of bold judicial moves, blended the two in theory and in practice. Judge Fernando Camacho had been a prosecutor

72. See Brooke Kintner, Note, The "Other" Victims: Can We Hold Parents Liable for Failing to Protect Their Children from the Harms of Domestic Violence?, 31 NEW ENG. J. ON CRIM. \& CIV. CONFINEMENT 271, 281-82 (2005).

73. See Steketee et Al., supra note 66, at 44.

74. See Cheryl Hanna, No Right to Choose: Mandated Victim Participation in Domestic Violence Prosecutions, 109 HARV. L. REv. 1849, 1891 (1996). See generally Evan Stark, A Failure to Protect: Unravelling "The Battered Mother's Dilemma," 27 W. ST. U. L. REV. 29 (2000) (discussing coercive control).

75. See SCHNEIDER, supra note 54, at 49-50, 184; Gruber, supra note 58, at 756 . The concept that these women completely lacked autonomy underlay some extreme proposals, such as calls to place coercively controlled women who refused to prosecute in legal guardianship for their own good. See, e.g., Ruth Jones, Guardianship for Coercively Controlled Battered Women: Breaking the Control of the Abuser, 88 GEO. L.J. 605, 609-10 (2000) (discussing the use of guardianship to facilitate the removal of an abused from an abuser's control).

76. See Donna Coker, Shifting Power for Battered Women: Law, Material Resources, and Poor Women of Color, 33 U.C. DAvIS L. Rev. 1009, 1044-45 (2000) (describing arrest and prosecution of victims for various charges including assault, child abuse, and neglect).

77. See supra Section I.A. 
overseeing gang cases involving juveniles and later became a judge in juvenile and DV court. ${ }^{78} \mathrm{He}$ was presiding over arraignments when he encountered a sixteen-year-old prostitution defendant who had a record of multiple prostitution arrests (New York criminal law treats sixteenand seventeen-year-old as adults). ${ }^{79} \mathrm{He}$ explains:

I just didn't think that she was out there of her own free will and she was making a knowing and voluntary decision that we should be prosecuting her as an adult for. So from that point on, rather than giving her a jail sentence I started looking for services for her. ${ }^{80}$

Judge Camacho managed to get all the prostitution cases involving sixteen- and seventeen-year-olds adjourned to his court, and persuaded prosecutors to accept diversionary sentences and services in lieu of short jail terms as the default penalty for this class of defendants. ${ }^{81} \mathrm{He}$ also began to emphasize therapeutic and community-based services for defendants. ${ }^{82}$ MCC and other New York-based community courts had of course already pioneered jail-diversionary approaches for prostitution offenses, but as one former CCI employee explains, these earlier courts did not conceptualize defendants as victims of violence. ${ }^{83}$

Judge Camacho credits his training and experience presiding over the DV court in crystallizing his view of prostitution as a product of "power and control" rather than autonomous choice. ${ }^{84}$ The judge explains:

[T] he power and control model in these workshops and seminars, that all of us attended prior to working in the domestic violence courts, explained why this young woman who is being prostituted, who is being beaten up every night, who is just living this hellish existence, isn't getting up and leaving. Why is she going back to track every day? Why is she going back at the end of the day and giving the pimp all her money? Why is she doing this? And I think the domestic violence area helped me understand why victims act in certain ways and how batterers are able to control their

78. See Changing Perceptions: A Conversation on Prostitution Diversion with Judge Fernando Camacho, CTR. FOR CT. INNOVATION (Jan. 2012), http://www.courtinnovation.org/res earch/changing-perceptions-conversation-prostitution-diversion-judge-fernando-camacho -0 [hereinafter Changing Perceptions].

79. Id.

80. Id.

81. Id.

82. Id.

83. Telephone Interview with Kristine Herman, Strategic Initiatives Specialist, Brooklyn Def. Servs. (June 10, 2014).

84. See Changing Perceptions, supra note 78. 
victims' behavior, using different mechanisms and different techniques. ${ }^{85}$

Over the next several years, under the DV paradigm of coercive control-which Judge Camacho applied to prostitution offenses-all Queens' prostitution cases, teenage and adult alike, became eligible for prostitution diversion court. ${ }^{86}$

This idea, that coercive control is a defense to prostitution charges, even if informally, would become a core justification for the HTICs. As Eliza Hook, Criminal Court Advocacy Coordinator at Girls Educational $\&$ Mentoring Services, testified to the New York City Council regarding the HTICs:

We make the comparison with domestic violence and say we would never criminalize a young woman for being a victim of domestic violence, yet when our young women are going through a very similar situation and are under the control of an exploiter and then arrested, they are identified as criminals . . . ${ }^{87}$

Significantly, CCI, which helped create the HTICs, adopted this view as well. Courtney Bryan, who joined CCI in 2008 as the Director of Criminal Justice Operations, helped expand the court reform project that Judge Camacho had begun. ${ }^{88}$ She had previously worked with battered women accused of a range of crimes and expressed frustration that they were treated like any other criminal ${ }^{89}$ While for years coercive control had been the explanation of why women stay with abusive men, the work of Judge Camacho, Bryan, and other DV reformers paved the way for coercive control to explain other poor choices, specifically involvement in prostitution..$^{90}$

85. Telephone Interview with Fernando Camacho, Court of Claims Judge and Acting Supreme Court Justice, N.Y. 10th Judicial Dist. (Dec. 17, 2014).

86. See Sarah Schweig et al., Ctr. for Court Innovation, Prostitution Diversion PROGRAMs 2-3, 10 (2012), http://www.courtinnovation.org/sites/default/files/documents/CI_Prostit ution\%207.5.12\%20PDF.pdf.

87. Oversight Transcript, supra note 57, at 63 (statement of Elizabeth Hook, Coordinator, Girls Educ. \& Mentoring Servs.).

88. Interview with Courtney Bryan, Dir., Ctr. for Court Innovation, in New York, N.Y. (June 23, 2014).

89. Id.

90. For more detail, see Amy J. Cohen \& Aya Gruber, Governance Feminism in New York's Alternative "Human Trafficking Intervention Courts," in GOVERNANCE FEMINISM: A HANDBOOK (Janet Halley et al. eds, forthcoming 2017) (on file with authors). 


\section{Prostitution as Human Trafficking}

By 2010, prostitution diversion courts were operating in Queens and Midtown. Queens consolidated eligible prostitution-related offenses (pimps, johns, and people charged with both prostitution and other types of offenses were ineligible) to a single court, now presided over by Judge Toko Serita, while MCC continued to amalgamate prostitution and other offenses. However, MCC employed a new social-work team dedicated to prostitution cases and, like Queens, began to reconceptualize women charged with prostitution, not as petty offenders, but as likely victims of domestic violence. In a few short years, prostitution diversion, which was happening in a piecemeal fashion and receiving minimal public attention, morphed into a statewide rollout of human trafficking intervention courts, full with extensive press coverage and international acclaim. And the concept of coercive control popularized in DV reform became trafficking in the context of prostitution. ${ }^{91}$ How did this happen?

At the same time as court reformers were reconceptualizing prostitution as domestic violence, an international movement was campaigning against prostitution using a language of torture, slavery, and trafficking. ${ }^{92}$ The public-awareness campaign against human trafficking and modern-day slavery proved so influential that fighting trafficking was the theme of President Barack Obama's 2012 speech to the Clinton Global Initiative. ${ }^{93}$ Stories of sex slavery featured prominently in his national anti-trafficking discourse. For example, the President stated, "When a little girl is sold by her impoverished family - girls my daughters' age-runs away from home, or is lured by the false promises of a better life, and then imprisoned in a brothel and tortured if she resists-that's slavery." 94

91. See supra notes $9-18$ and accompanying text.

92. See, e.g., Siddharth Kara, Sex Trafficking: Inside the Business of Modern SlaVERY, at ix (2009); DANIEL WALKER, GOD IN A BROTHEL: AN UNDERCOVER JOURNEY INTO SEX TrafFicKInG AND ReSCUE 9 (2011); Melissa Farley, Prostitution, Trafficking, and Cultural Amnesia: What We Must Not Know in Order To Keep the Business of Sexual Exploitation Running Smoothly, 18 YALE J.L. \& FEMINISM 109, 110-12 (2006).

93. Press Release, Pres. Barack Obama, Remarks by the President to the Clinton Global Initiative, The White House (Sept. 25, 2012), https://www.whitehouse.gov/the-press-office/2012/ 09/25/remarks-president-clinton-global-initiative.

94. Id. While President Obama referred to many forms of coerced labor as human trafficking (i.e., domestic work, agriculture, healthcare, etc.), id., for many, the paradigmatic example of modern slavery is sex trafficking. Indeed, feminist activists fought to make this case. As Norma Ramos, Co-executive Director of the Coalition Against Trafficking in Women, argued to New York City lawmakers: "I want to note the distinction between labor and sex trafficking. UN statistics say that 80 percent of all human trafficking is that of women and girls, and 70 percent of that trafficking is for commercial sexual exploitation." Resolution Urging the United States Senate to Pass the United States House of Representatives' Version of the William Wilberforce 
Given this powerful rhetoric, the challenge for New York feminist activists and architects of the HTICs was to bridge the distance in the public's imagination between the imprisonment and torture of a child in some far-away third-world country on the one hand, and domestic "street" prostitution, on the other. They had to make the case, as one lawmaker said, that trafficking was an "international problem [with] local manifestations ... [that] seeps into the life of every community." 95 How these activists and reformers merged transnational sex trafficking and domestic prostitution is a complicated story involving many factors. Here we briefly sketch some of the ways in which U.S. domestic feminism influenced the transnational discourse on gender violence and how this discourse, in turn, influenced New York feminists and court reformers.

In the 1970s, a group of feminists in San Francisco formed Women against Violence in Pornography and the Media (WAVPM) to oppose prostitution and pornography, which they saw as inextricably linked to male dominance. ${ }^{96}$ This initiated what is commonly referred to as the "sex wars." "97 Anti-pornography feminists, most famously Andrea Dworkin, and Catharine MacKinnon, characterized commercial sex as the very embodiment of patriarchy. ${ }^{98}$ Pornography regulation drew the spotlight in the sex wars, but critiquing societal tolerance for prostitution was a significant part of that feminist agenda. As early as the 1970s, original WAVPM member Kathleen Barry started describing prostitution as slavery. ${ }^{99}$ She would go on to coin the phrase "sexual slavery" and her

Trafficking Victims Protection Reauthorization Act, 2006-2009 Sess. 28 (N.Y.C. Council 2008) [hereinafter Ramos Trafficking Statement] (statement of Norma Ramos), http://legistar.council.n yc.gov/Legislation.aspx (search "1329-2008" for the Session 2006-2009; then follow the "Res 1329-2008" hyperlink in the results; then follow the "Hearing Transcript 6/11/08" hyperlink in the Attachments row on the resulting webpage).

95. Resolution Calling upon the State of New York to Recognize that Human Trafficking Is a Crime and to Pass Legislation Criminalizing Human Trafficking and Providing Services and Programs to Trafficking Victims: Hearing Before the Committee on Women's Issues, 2006-2009 Sess. 76 (N.Y.C. Council 2006) [hereinafter Resolution Transcript] (statement of James Sanders, Council Member, N.Y.C. Council) (emphasis added), http://legistar.council.nyc.gov/Legislation. aspx (search "0504-2006" for the year 2006; then follow the "0504-2006" hyperlink in the results; then follow the "Hearing Transcript 9/28/06" hyperlink in the Attachments row on the resulting webpage).

96. See Lisa Duggan \& Nan D. Hunter, Sex Wars: Sexual Dissent and Political Culture 22 (2006); Evelina Giobbe, Confronting the Liberal Lies About Prostitution, in THE SeXual Liberals and tHE ATTACK ON FeminISM 67, 76 (Dorchen Leidholdt \& Janice Raymond eds., 1990).

97. See DugGan \& HuNTER, supra note 96, at 1.

98. See id. at 23,25 .

99. Kathleen Barry, Female Sexual Slavery 215 (1979); see also Janet A. Flammang, Women's Political Voice: How Women are Transforming the Practice and STUDY OF POLITICS 281 (1997) (discussing Kathleen Barry's early work). Similarly, Catharine MacKinnon in the early 1990s adopted the term "slavery" as a descriptor of pornography. See 
book of the same name, published in 1979, is currently a go-to text of the abolitionist anti-trafficking movement. ${ }^{100}$ Foreshadowing the HTICs, Barry blurred the distinction between prostitution and slavery: "Identifying women as sexual beings who are responsible for the sexual service of men is the social base for gender-specific slavery." 101

But the anti-pornography, prostitution-as-sexual-slavery camp never did win the sex wars. ${ }^{102}$ The movement was besieged from many sides: by popular columnists who described sex and sexual encounters as positive choice, by civil libertarians who worried about speech and due process, by sex-positive feminists who saw liberatory promise in female sexuality, by postmodern feminist theorists, and even by a burgeoning sex-worker's rights movement. ${ }^{103}$ In the wake of this defeat, radical feminists moved on. Specifically, they moved abroad.

In the 1990s, many western feminists, including Catharine MacKinnon, turned their attention away from the domestic sex wars to wartime sex crimes and the problem of human trafficking. ${ }^{104}$ Media coverage and political commentary exposing the lurid details of international sex-trafficking rings spurred widespread interest and a 2000 UN protocol. ${ }^{105}$ Once stories of foreign men kidnapping and bringing vulnerable women to U.S. shores in bondage reached the American public, lawmakers were swift to pen proposals to address the "epidemic" of human trafficking. ${ }^{106}$ One expert explains: "[L]egal scholars,

Catharine A. MacKinnon, Prostitution and Civil Rights, 1 MiCH. J. GENDER \& L. 13, 14, 30 (1993). Comparing hearings on the infamous Minneapolis anti-pornography ordinance to the Nuremburg trials, MacKinnon argued that "[t]hrough its production, pornography is a traffic in female sexual slavery. Through its consumption, pornography further institutionalized a subhuman, victimized, second-class status for women . . . " CATHARINE A. MACKINNON, ARE WOMEN HUMAN?: AND OTHER INTERNATIONAL Dialogues 88 (2006).

100. See FLAMMANG, supra note 99, at 281.

101. BARRY, supra note 99 , at 103.

102. See Bridget J. Crawford, Toward a Third-Wave Feminis. Legal Theory: Young Women, Pornography and the Praxis of Pleasure, 14 MICH. J. GENDER \& L. 99, 153 (2007).

103. See Am. Booksellers Ass'n v. Hudnut, 771 F.2d 323, 325 (7th Cir. 1985), aff d, 475 U.S. 1001 (1986); Kathryn Abrams, Sex Wars Redux: Agency and Coercion in Feminist Legal Theory, 95 Colum. L. Rev. 304, 304 (1995); Crawford, supra note 102, at 135, 138-39.

104. See Catharine A. MacKinnon, Trafficking, Prostitution, and Inequality, 46 HARV. C.R.C.L. L. REv. 271, 274-76 (2011); see also Karen Engle, Considering Some Consequences of "Calling in the Troops," 100 AM. SOC'Y INT'L L. PROC. 118, 118 (2006); M. Mariana Valverde, The Rescaling of Feminist Analyses of Law and State Power: From (Domestic) Subjectivity to (Transnational) Governance Networks, 4 U.C. IRVINE L. REv. 325, 326-27, 332 (2014).

105. G.A. Res. 55/25, at 32 (Nov. 15, 2000).

106. See Victims of Trafficking and Violence Protection Act of 2000, Pub. L. No. 106-386, 114 Stat. 1464 (codified as amended at 22 U.S.C. $\$ \S 7101-7113$ (2012)); see also Press Release, Polaris Project, Majority of States Actively Passing Laws to Combat Human Trafficking (Aug. 7, 2012), http://www.ncdsv.org/images/PP_MajorityState'sActivelyPassingLawsCombatHuman Trafficking_NR_8-7-2012.pdf (noting an increase in legislation evidenced in that "47 states and 
lawmakers, advocacy groups and the media have consistently used an eroticized version of the female 'sex slave' to justify and garner public support for anti-trafficking legislation." ${ }^{07}$ But it was precisely because this anti-trafficking fervor of the early 2000 s invoked foreign, exotic, and spectacular practices that it initially evaded the thorny issues of the sex wars of the past: Even the drafters of the UN protocol were "explicit on the point that the [sex trafficking] definition did not operate to regulate or even pronounce on prostitution." 108

When New York advocates and lawmakers initially took up the antitrafficking cause, they too made clear that they were attacking trafficking, not prostitution. In 2007, the New York State Legislature passed an AntiTrafficking law, in the wake of publicity that New York was a major port of entry into the United States for trafficked women. ${ }^{109}$ Under the law, a person has been trafficked when another "advances or profits from" their prostitution by means of various coercive behavior including providing drugs, debt bondage, physical harm and coercion, and even "false statements" or "any other act . . . which is calculated to harm the person." "While this could describe many cases of prostitution, early interpretations of New York's anti-trafficking law did not necessarily conceive of the "ordinary street prostitute" as a trafficking victim. New York's interagency task force charged with reporting on the law, for example, continued to envision sex trafficking as involving transnational transport and direct coercion through force, threats, confiscating passports, or debt bondage. ${ }^{111}$ Similarly, in a 2008 New York City Council meeting debating whether to pass a bill to support a more radical version of federal anti-trafficking legislation, Norma Ramos, the executive director of the Coalition Against Trafficking in Women (CATW), made clear: "The opposition consistently tried to turn our efforts into a debate about prostitution, which this is not. ... CATW has

D.C., have sex trafficking criminal statutes, and 49 states and DC have labor trafficking criminal statutes").

107. Cynthia L. Wolken, Feminist Legal Theory and Human Trafficking in the United States: Towards a New Framework, 6 U. MD. L.J. RACE, RELIGION, GENDER \& ClASS 407, 410 (2006).

108. anne T. Gallagher, The International law of Human Trafficking 50 n.164 (2010).

109. N.Y. Penal LaW $\S 230.34$ (McKinney 2016) (effective Nov. 1, 2007); MIA Spangenberg, ECPAT-USA, International Trafficking of Children to NeW York City FOR SEXUAL PURPOSES 8 (2002), http://www.childtrafficking.com/Docs/ecpat_2002_internationa 1_trafficking_children_new_york_sexua.pdf.

110. N.Y. PENAL LAW § 230.34.

111. See Denise E. O’Donnell \& David A. Hansell, interagency Task Force, New

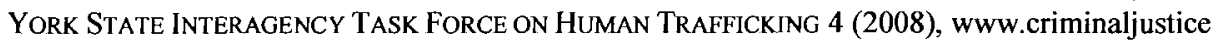
.ny.gov/pio/humantrafficking/human_trafficking_rpt_aug08.pdf. ("Victims are trafficked into the United States from all over the world, within U.S. borders, and within other countries. They are frequently found enslaved in prostitution...."). 
consistently stated that trafficking requires a trafficker, and that this is not a bill designed to go after prostitution, only trafficked prostitution which requires a trafficker."112

Contemporaneously, a separate group of reformers (including juvenile justice advocates, family court lawyers, and the organization Girls Educational \& Mentoring Services (GEMS)), who were concerned more with improving the welfare of minors engaged in prostitution than with eradicating transnational human trafficking, pushed for changes to lessen the harsh effects of criminalization. ${ }^{113}$ Describing minors involved in commercial sex as victims, rather than perpetrators, this group achieved a legislative milestone in the form of the 2008 Safe Harbour for Exploited Children Act, ${ }^{114}$ which deems all minors engaging in prostitution sexually "exploited children."115 The law modified the family courts' treatment of "juveniles" (defined as fifteen-year-olds or younger) charged with prostitution offenses, creating a presumption that such juveniles are "person[s] in need of supervision" rather than "delinquents." 116

The primary driver of the Safe Harbour Act was a concern with the harsh treatment of minors in New York's family and criminal courts. Nevertheless, groups primarily focused on enacting anti-trafficking laws also saw the legislation as a victory for their cause. Safe Harbour ultimately presaged a wave of trafficking-related legislation. In 2009, the

112. Ramos Trafficking Statement, supra note 95. This sentiment also appeared before, at a 2006 hearing, where one New York lawmaker opined: "When [prostitutes] are picked up ..., they're picked up because they have committed an offense. Trafficking is very different. It is extremely different. They haven't committed any offense .... [T] [Tere needs to be a shifting of gears in separating human trafficking and prostitution ...." Resolution Transcript, supra note 95, at 46-47 (statement of Helen Sears, Chairperson, Comm. on Women's Issues) (emphasis added).

113. See Katherine Mullen \& Rachel Lloyd, The Passage of the Safe Harbor Act and the Voices of Sexually Exploited Youth, in LAWYER's MANUAL On HUMAN TRAFFICKING: PURSUING JUSTICE FOR VICTIMS 129, 130 (Jill Laurie Goodman \& Dorchen Leidholdt eds., 2011).

114. 2008 N.Y. Sess. Laws ch. 569 (A. 5258-C) (McKinney 2016).

115. N.Y. SOC. SERV. LAW $\S \S 447$-a, 447-b (McKinney 2016); Mullen \& Lloyd, supra note 113 , at 134.

116. N.Y. FAM. CT. ACT $\$ 311.4(2)$ (McKinney 2016). Until recently, it was unclear how the Safe Harbour Act affected minors considered aduits in the N.Y. system (sixteen- and seventeenyear-olds) arrested for prostitution offenses. In 2014, months after the HTIC rollout, the New York State legislature clarified that a criminal court judge could also utilize some of the Safe Harbour provisions in an adult criminal prostitution case involving a sixteen- or seventeen-yearold. N.Y. CrIM. Proc. $\$ \S 170.30,170.80$ (McKinney 2016). The legislature also provided additional dispositional alternatives that include a dismissal of the criminal charges in the interest of justice and a mandate that if the defendant is found guilty, either by plea or at trial, she (or he) be adjudicated a youthful offender. $\$ 170.30$. In practice, this has produced mixed results, with a handful of cases dismissed in the interest of justice, some cases resolved by joint family and criminal court supervision, and some cases resolved by traditional criminal court process. 
legislature passed a provision to allow adult defendants with a record of prostitution to vacate previous convictions when "the defendant's participation in the offense was a result of having been a victim of sex trafficking." I17 In 2015, New York State ushered in another "comprehensive" anti-trafficking bill, the Trafficking Victims Protection \& Justice Act, which, among other things, further enhanced the penalties for those convicted of trafficking and created several new traffickingrelated crimes. ${ }^{118}$

Thus, the newfound public interest in trafficking created the opportunity for activists to renew a sex-war offensive against domestic prostitution and to blur the legal and factual distinctions between prostitution and trafficking in ways that MacKinnon and others had in the international and transnational context. ${ }^{119}$ Indeed, architects of the HTICs explicitly imported the international discourse against trafficking and redescribed it as domestic prostitution. For example, Judge Kluger made clear that "trafficking is as much an issue domestically as it is internationally. In the United States, about 80 percent of the victims involved in sex trafficking are citizens .... Many of these victims end up in court as defendants charged with prostitution-related offenses."'120 Thus, "by and large," she explained, in the HTICs "we work under the assumption that anyone who's charged with this kind of crime is trafficked in some way. ... [Y] ou can be trafficked from Brooklyn to Manhattan ...."121 Or, to put this point another way, the idea of coercive control, familiar in domestic violence reform, had become "trafficking" in the context of prostitution. This is how, as another judge explained, the

117. N.Y. CRIM. Proc. $\S 440.10$. Unlike the Safe Harbour Act, the vacatur statute requires the defendant to make a motion to the court establishing by a preponderance of the evidence that she is a victim of sex trafficking provided in N.Y. or federal anti-trafficking law and that her participation in the prostitution offense for which vacatur is sought was a result of that trafficking. See id.

118. See supra note 56.

119. See generally Catharine MacKinnon, Sex Equality Under the Constitution of India: Problems, Prospects, and "Personal Laws," 4 INT'L J. CONST. L. 181 (2006) (discussing the problem of commercial sex in India). Although the feminist anti-pornography camp recently seemed all but extinct, the trafficking debate has revived even that aspect of the sex war. Deborah Dinner, A Firebrand Flickers, LEGAL AFFAIRS (Mar.-Apr. 2006), http://www.legalaffairs.org/iss ues/March-April-2006/review_Dinner_marapr06.msp ("MacKinnon's categorical opposition to pornography appears out of touch with today's culture."); see, e.g., Melissa Farley et al., Online Prostitution and Trafficking, 77 ALB. L. REv. 1039, 1039, 1044 (2014); Rachel N. Busick, Note, Blurred Lines or Bright Line? Addressing the Demand for Sex Trafficking Under California Law, 42 PEPP. L. Rev. 333, 347 (2015) (stating that pornography "can be both a form of sex trafficking and a major contributing factor of demand" (footnote omitted)).

120. Oversight Transcript, supra note 57, at 12-13 (statement of Judy Kluger, Judge, N.Y.C. Criminal Court).

121. Id. at 38 (emphasis added). 
HTICs operate under a presumption of trafficking: "Defendants in the courts, most of whom are women, should be perceived as either victims of human trafficking or in a group that is at high risk for trafficking."122 Having sketched how this ideology came to be, Part II turns to a detailed exploration of how it fares in practice.

\section{The Human Trafficking InTERVEntion COURTS}

The HTICs are creatures of judicial decree; there are no foundational documents outlining their parameters. Judge Lippman set forth the description of the courts in very general terms: Prostitution cases not resolved at arraignment should be diverted to a single court with "a presiding judge who is trained and knowledgeable in the dynamics of sex trafficking and the support services available to victims[,]" giving prostitution defendants the opportunity for "appropriate services" and noncriminal dispositions. ${ }^{123}$ Given this description, a N.Y. court could change little and continue to resolve the vast majority of prostitution cases at arraignment through quick guilty pleas, sending only a few cases of clearly trafficked defendants amenable to services to the HTICs. Conversely, the directive could be interpreted to mean that every case involving prostitution, even those with multiple non-prostitution charges, must go to the HTICs and eventually be dismissed. In reality, the courts we examined all fell somewhere between these two poles. Consider the case below, which illustrates how courts employ a mix of old and new criminal procedure.

\section{Anna's case}

An attractive young woman sits quietly next to us on a gray plastic hallway chair outside of the HTIC, in the basement of a New York City criminal courthouse. "Anna" came to court early and is the first to enter the courtroom when the court officer unlocks the doors. The courtroom shortly begins to fill, and Anna sits in the back row. The gender make-up of the court is striking: it is full of women. The attorneys and social workers are for the most part women. The defendants are all womenoverwhelmingly women of color-both U.S.- and foreign-born, cis- and trans-gender. ${ }^{124}$ The few men in the courtroom consist of court officers and clerks, some prosecutors, and the defendants' companions. According to many HTIC personnel, these companions are probably traffickers there to oversee the trafficking victims' cases or, worse, do some recruiting. The court officer declares "all rise," and a small

122. Interview with Toko Serita, supra note 55.

123. Lippman, supra note 9.

124. See supra note 14. 
bespectacled female figure appears at the bench. She resolves cases quickly and speaks to the defendants in a direct New York style, but she uses gender-sensitive pronouns, makes eye contact, and laces her matterof-fact voice with a tinge of sympathy-a manner that, she later told us, is quite deliberate.

Anna's case is called. She comes forward and is surrounded by a cadre of attorneys and social workers. The judge speaks first: "I just want to make an observation, if the Court may, as to how changed for the better I notice the defendant is today." 25 Anna quietly replies, "Thank you." 26 The attorneys approach the bench leaving Anna alone at counsel table and engage in a discussion with the judge that, although brief, feels interminable as Anna and the rest of us watch the attorneys' gesticulations in silence. The parties go back on the record. The judge again does the talking, this time addressing the topic of Anna's child:

The Court: "Look at the big picture. And remember it's not [babies'] fault if they are crying for hours on end."

The Defendant: "He doesn't cry."

The Court: "If he does, keep in mind that's part of his job, that's his way of telling you something's up. . . . Going in a forward momentum, you can stay with him and he can stay with you." "27

Two weeks before, that same judge had ordered Anna detained indefinitely at Rikers Island and separated from her four-month-old child, prompting an intense courtroom scene in which Anna banged her head against the floor, screamed out in agony, and had to be physically restrained by officers. ${ }^{128}$ Anna spent the ensuing week in jail, primarily in the medical unit.

Why had the judge incarcerated her? Had she harmed her child? Anna was on the docket of the very first HTIC session in her jurisdiction. During the initial months of the court, Anna had two open prostitution cases and was complying with a court mandate that she meet with a service provider as a prerequisite to a favorable disposition of her cases. She had completed four out of the five mandated service sessions assigned to her when she was arrested on a third prostitution charge. ${ }^{129}$

125. Transcript of Record at 2, Sealed Proceeding, No. 2013BX060593 (Bronx Crim. Ct. June 26,2014 ) (on file with authors).

126. $I d$.

127. Id. at 3 .

128. Transcript of Record at 7, supra note 125.

129. Interview with Aisha Lewis-McCoy, Attorney, Legal Aid Soc'y, in New York, N.Y. (June 26, 2014). 
Because she had failed to appear for her second case (the court would later learn this was because she had been hospitalized for mental health treatment on the date of her hearing ${ }^{130}$ ), on her third arrest the arraigning judge, who was not part of the HTICs, set a $\$ 2,500$ bail. ${ }^{131}$ Unable to post this amount, she was sent to Rikers Island.

A few days after her initial detention, Anna appeared in the HTIC. Anna's physical appearance was shocking-she had a black eye and broken teeth. Anna's injuries had in fact occurred in jail, but in the courtroom, assumptions about the source of her injuries ran rampant. Anna's attorney explains, "She comes out. She's been visibly beaten up, and I think that sets off alarms [about domestic violence] . . . because I think that if you haven't represented a human being who's been in custody and if you've never visited any jails, you might think that jail is a safe place for people." 132 In addition, during a previous hearing on her cases, the social worker, to show Anna's progress, had disclosed to the judge and prosecutor that Anna was trying to leave her intimate-partner pimp. ${ }^{133}$ Thus, although the arraignment judge initially incarcerated Anna as a flight risk, now the HTIC judge and prosecutor were inclined to keep her in jail to protect her from her presumably abusive trafficker. The prosecutor later explained:

It was appropriate for bail to have been set because she continued to engage in prostitution with a child and she had bench warranted in the past, which is what bail had to correct. In order to consent to her release, however, we wanted to ensure that she had a place where she was safe from her trafficker and thus able to return to court. ${ }^{134}$

Against the prosecutor's arguments to keep Anna incarcerated, Anna's attorney and social worker urged the HTIC judge to release Anna to her aunt, allow Anna to attend her final service session, and reunite her with her newborn. ${ }^{135}$ However, both the judge and the prosecutor doubted the validity of the aunt's willingness to provide housing, and insisted that the defender or social worker line up a bed in a DV shelter. ${ }^{136}$ Anna's

130. Id.

131. Transcript of Record at 4, No. 2014BX030650 (Bronx Crim. Ct. June 8, 2014) (on file with authors); see also infra notes 191-93 and accompanying text (discussing the N.Y. bail process).

132. Interview with Aisha Lewis-McCoy, supra note 129.

133. Id.

134. Interview with Hannah Freilich, Bronx Assistant Dist. Attorney, in New York, N.Y. (June 26, 2014).

135. Transcript of Record at 3-4, Sealed Proceeding, No. 2013 BX060593 (Bronx Crim. Ct. June 12, 2014) (on file with authors).

136. Id. at 7 . 
attorney explained that shelter beds were limited and that shelters require a detailed screening and a showing of immediate danger prior to admittance, which is nearly impossible for an incarcerated person to complete and demonstrate. But the prosecutor and the judge were unpersuaded. The judge informed Anna that she would go back to Rikers, prompting the violent and agonizing spectacle in the courtroom. ${ }^{137}$

A week later, Anna returned to court for a review, having spent twelve days in jail-longer than most prostitution jail sentences. ${ }^{138}$ During Anna's incarceration, her lawyer obtained proof that Anna had been voluntarily seeking psychiatric treatment and counselors had put together a structured plan for her that involved, at least temporarily, residing with her aunt. "I wasn't trying to make [the prosecutor] feel terrible but I wanted her to understand [her] complicity-like you don't get to say 'well this person got arrested and they put themselves in this position' while you're working in a [human trafficking] intervention court."139 Upon the attorney's word that she would continue to try to get Anna a placement in a DV shelter and upon the condition that Anna come back to court quickly and frequently so that the prosecution could monitor her, the D.A. assented to Anna's release. The judge, accordingly, finally, released her. ${ }^{140}$

Unlike Anna, most defendants in the HTICs are not subject to pretrial detention. Nevertheless, her case illustrates some of the internal contradictions of a court that views criminal defendants as victims and seeks to help those victims through the institution of criminal prosecution. On the one hand, Anna was treated like an ordinary criminal: HTIC philosophy could regard multiple prostitution cases and even bench warrants as indicating that the woman is multiply victimized and trafficked, yet in criminal court multiple cases and bench warrants trigger a pretrial process concerned with re-offense and flight and a disposition process that holds repeat offenders more accountable than first-timers. On the other hand, Anna was subject to arguments for detentionnamely, generalized concerns for her safety-that would hardly suffice to justify the incarceration of other kinds of criminal defendants. ${ }^{141}$

Thus, this case illustrates the complex and often inconsistent ways in which the idea of victimhood influences criminal court procedure. From the perspective of the defense attorneys we interviewed, the idea of the

137. Id.

138. Transcript of Record at 2, Sealed Proceeding, No. 2013BX060593 (Bronx Crim. Ct. June 19, 2014) (on file with authors).

139. Interview with Aisha Lewis-McCoy, supra note 129.

140. Transcript of Record at 3, supra note 138 .

141. See, e.g., N.Y. MENTAL HYG. LAW $\S 9.39$ (McKinney 2016) (stating that mental health holds are reserved for cases in which the defendant, himself, poses a substantial risk of harm to himself or others). 
victim-defendant does too much work: Anna was kept incarcerated, in part, for her own good. But it also, ironically, does too little: Anna was repeatedly arrested, processed in court, and incarcerated on a bench warrant. The new trafficking paradigm thus sits uneasily together with the older understanding of prostitution defendants as opportunistic criminal actors. Indeed, in a second case we observed the same morning as Anna's, the defendant was subject to eviction from her apartment under the New York bawdy house statute because she allegedly engaged in prostitution in her home. ${ }^{142}$ When we later asked the prosecutor if she thought eviction was appropriate given the HTICs' presumption that defendants are trafficking victims, she responded:

It depends on the context of each case. In the case of this particular defendant, children live in the home. If she has real claims of safety, for example, if this is her trafficker's home, then she should come and talk to us. If this is her home, then why is prostitution going on there? ${ }^{143}$

As this quotation suggests, prosecutors try to resolve tensions between the old (traditional or prosecutorial) and new (victim-based) court paradigms by asking for explicit evidence of trafficking ("real claims of safety").

But, in one of the most stunning complications of the court, this evidence is hardly ever forthcoming. Many prostitution defendants do not consider themselves trafficked and decline to disclose evidence of trafficking, even if doing so is in their legal interest. ${ }^{144}$ Many defense attorneys urge judges not to describe their clients as trafficked in open court to prevent discomfort, trauma, and even danger, given that a trafficker might be present. One young defense attorney described this absence of discussion about trafficking as a source of professional frustration: "I don't really think I am really engaged in trafficking work per se ... it's just like I'm preventing people from being incarcerated, you know, and with an eye towards the fact that they might have a lot of trafficking issues." 145 Indeed, outside of press interviews, many of those working in the HTICs rarely refer to the court by its official name, preferring the much less colorful title "AP8," the administrative

142. See supra note 26 and accompanying text (discussing Bawdy House laws).

143. Interview with Hannah Freilich, supra note 134.

144. Defense attorney Ting Ting Cheng, for example, described a situation where she was trying to obtain a "T Visa" for a trafficked client from Mexico. Interview with Ting Ting Cheng, Attorney, Brooklyn Def. Servs., in New York, N.Y. (June 25, 2014). The client had already been deported twice for prostitution, but the client refused to say that she had been trafficked. Id.

145. Id. 
designation of the court section. ${ }^{146}$ Below we outline practice before the HTICs in order to analyze just what is different about processing prostitution cases in the human trafficking intervention courts today.

\section{A. The Practice Prior to the Human Trafficking Intervention Courts}

In the years immediately preceding the HTICs, other than in a few select courtrooms, such as Queens and the Midtown Community Court, New York City prostitution cases proceeded like other misdemeanors. Prostitution defendants entered the system through on-the-street arrests for loitering or vice arrests involving undercover operations. In addition, police anti-trafficking task forces performed intermittent raids on businesses (i.e. massage parlors) believed to be prostitution dens and arrested both suspected promoters and workers. ${ }^{147}$ Although there has now been talk of training police officers in administering trafficking assessments during arrests, at the time of writing, these policing practices and the resulting arrests continue unchanged. ${ }^{148}$

Before the HTICs, prostitution offenses, like other petty offenses, were either resolved at arraignment or, if continued, sent to an undifferentiated misdemeanor courtroom. ${ }^{149}$ Prostitution defendants made their first appearances with other arrestees in front of a judge presiding over arraignments. ${ }^{150}$ At that time, most prostitution cases were simply disposed of by plea bargain, and those not immediately resolved were sent on to general misdemeanor courts for resolution. ${ }^{151}$

146. See, e.g., Spotlight on the Bronx Defenders' New Prostitution Conviction Vacature Project, BRONX DEFENDERS (Aug. 7, 2014), http://www.bronxdefenders.org/spotlight-on-thebronx-defenders-new-prostitution-conviction-vacature-project/. "AP" stands for all-purpose, and is used in the New York City court system to reference a misdemeanor courtroom that handles cases in a variety of postures post-arraignment. CRIMINAL COURT OF THE CITY OF N.Y., 2014 ANNUAL REPORT 39 (2015). In most county criminal courts, there are at most seven pre-existing all-purpose parts. See id. The designation AP8 reflects nothing specific about trafficking or prostitution, it simply represented, at the time, the next unassigned numerical value that could be used by each county.

147. See infra notes 291-302 and accompanying text (discussing massage parlor raids).

148. See, e.g., Kate Mogulescu, The Public Defender as Anti-Trafficking Advocate, an Unlikely Role: How Current New York City Arrest and Prosecution Policies Systematically Criminalize Victims of Sex Trafficking, 15 CUNY L. REV. 471, 488 (2012) (discussing the absence of adequate training for New York police officers); Press Release, Governor Cuomo Announces New Human Trafficking Awareness Efforts (Jan. 13, 2015), https://www.governor.ny.gov/news/ governor-cuomo-announces-new-human-trafficking-awareness-efforts (quoting Michael C. Green, Executive Deputy Commissioner of the State Division of Criminal Justice Services, who pledged to "help ensure that police and prosecutors have the training that allows them to handle these difficult cases"). On arrest numbers, from 2006 to 2012, there were an average of 2,410 arrests each year throughout New York State for Penal Law $\$ 230.00$, prostitution offenses. See N.Y. Div. of Criminal Justice Servs., supra note 14. In 2013, the year of the HTIC rollout, there were 2,482 , followed by 2,272 the following year. $I d$.

149. See Kohler-Hausman, supra note 36 , at 654 (discussing this process).

150. See id.

151. See supra Section I.A. 
The actual disposition of prostitution cases differed from county to county, judge to judge, and case to case, but it was quite common for a prostitution defendant to plead guilty to a misdemeanor or violation, be convicted, and receive a short jail term, time served, or a sentence of community service or a fine. ${ }^{152}$ Nevertheless, even before the HTICs, defendants could receive an "adjournment in contemplation of dismissal" (ACD), an alternative disposition where the judge continues the case for a period of time, with or without conditions, and if after that period of time, the defendant has no new offenses and has completed conditions, the case is dismissed and sealed. ${ }^{153}$ Cases resolved through ACDs entail no finding or adjudication of guilt, and in accordance with New York state law, will not appear on a public background check once dismissed and sealed. ${ }^{154}$ Yet this sought-after disposition was far from the default for prostitution cases prior to the HTICs. ${ }^{155}$

Like most misdemeanants, prostitution defendants faced a revolving cast of characters. Outside of Queens - which employed a dedicated prostitution-court judge, prosecutor, and defender-prostitution cases made up a portion of many different judges' dockets and many different prosecutor and defender caseloads. Thus, two prostitution defendants might have very divergent experiences depending on the judging, prosecution, and defending styles of the state actors they encountered. Some judges could be dismissive and belittling, while others exhibited compassion and empathy. Some judges prized efficiency and quick case resolution, while others believed in the benefit of a prolonged in-court interaction. Prosecutors and defenders also adopted a range of styles in handling prostitution cases. In 2011, several years before the HTIC rollout, the Legal Aid Society of New York, the primary public defender in New York City, centralized the defense of prostitution cases in Manhattan in an attempt to improve its representation of this group of defendants. ${ }^{156}$ This centralized approach expanded in 2013, several

152. In 2008, for example, 2,067 , or $76 \%$, of the arrests in New York City for Prostitution, P.L. $\$ 230.00$, or Loitering for the Purpose of Engaging in a Prostitution Offense, P.L. $\$ 240.37$, were resolved by a conviction as a result of a guilty plea. N.Y. Div. of Criminal Justice Servs. NYC Prostitution Dispos as of 7-21-2015, Computerized Oracle File (July 21, 2015). Of those cases, 545 defendants $(26 \%)$ were sentenced to jail, 376 defendants $(18 \%)$ were sentenced to "time served," and 93 defendants $(4 \%)$ were sentenced to pay fines. Id. The rest received a conditional discharge, or a non-jail sentence with specific conditions, usually the completion of community service. $I d$.

153. N.Y. CRIM. Proc. LAW $\S 170.55$ (McKinney 2016).

154. See id. $\$ 170.55(8)$; see also id. $\$ 160.50(3)$.

155. In 2008,361 out of 2,711 closed cases (13\%) were resolved with an Adjournment in Contemplation of Dismissal. N.Y. Div. of Criminal Justice Servs., supra note 152.

156. Legal Aid Expands Program for Trafficking Victims, LEGAL AID SOC'Y (Mar. 22, 2013), http://www.legal-aid.org/en/mediaandpublicinformation/inthenews/legalaidexpandsprogramfortraf fickingvictims.aspx. 
months before the HTIC announcement, to include dedicated prostitution defenders in each borough under the direction of one supervisor, coauthor Kate Mogulescu. ${ }^{157}$

Before the HTICs, whether services entered the picture was also highly variable. Many prostitution offenders pleaded guilty to misdemeanors or violation-level offenses without services. This fact underlies the criticism, discussed earlier, that prostitution cases were "disposable" or merely the "go away" cases. ${ }^{158}$ By contrast, some courts, notably Queens and the Midtown Community Court in Manhattan, featured dedicated social workers who offered service programs to defendants. ${ }^{159}$ The Brooklyn D.A.'s Office created and ran two highly publicized anti-prostitution programs, with the primary focus of extracting information that would help law enforcement arrest johns, promoters, traffickers, and prostitutes as well. ${ }^{160}$ However, access to those programs was sporadic and compliance rates poor. ${ }^{161}$

In sum, in the years immediately preceding the HTICs, there was no single model of prostitution prosecution and adjudication. Like other misdemeanors, many prostitution cases were characterized by plea bargaining, minor convictions, short sentences, variability in representation and interaction with court personnel, and inconsistency in services. Yet experimentation was occurring on a piecemeal basis in some courthouses, and Legal Aid had already centralized its prostitution defenders. Today, disparities in judging styles persist, even within the trafficking courts, and D.A.'s offices continue to rotate new prosecutors through these courts, creating variability. Nonetheless, several formal and cultural norms have lent a measure of uniformity to HTIC court practice. Below we describe several specific features of the HTICs designed to institutionalize state-wide change-centralization, court culture, alternative dispositions and service mandates, treatment of repeat

157. Id.

158. As Judge Serita said: " $[E]$ verybody working in criminal court was historically complicit in this idea that prostitution cases were the go-away cases, that you just resolve them as soon as you can and make them disappear." Interview with Toko Serita, supra note 55.

159. See SCHWEIG ET AL., supra note 86, at 4, 6, 9.

160. See Samuel Newhouse, Spreading the Word About Stopping Prostitution, BrooKLYN EAGLE (May 14, 2010), http://50.56.218.160/archive/category.php?category_id=4\&id=35420 (discussing EPIC and STAR programs administered by the Brooklyn D.A. office). One insider revealed to us on the condition of anonymity that through the "EPIC/STAR program, [prosecutors], try to record patterns of entry into prostitution. [They] also try to record names of pimps. [They] gather a database of the names of pimps and the areas in which pimps operate" in order "to end prostitution ... or at least reduce its appearance in Brooklyn." Telephone Interview with Anonymous HTIC Staffer, New York, N.Y. (July 11 2014).

161. The EPIC/STAR program was discontinued in 2015, and now the Brooklyn HTIC, like the others, uses service providers not affiliated with the prosecutors' office. Telephone Interview with Anonymous HTIC Staffer, supra note 160. 
offenders, and relationship to trafficking prevention and interdictionand the convergences and variations in courts' approaches to these components.

\section{B. The Practice in Human Trafficking Intervention Court}

\section{Centralization}

The key feature of the HTIC system is the consolidation of prostitution-related cases in front of a single judge, who is trained on the dynamics of human trafficking. ${ }^{162}$ After the establishment of the HTICs, the number of prostitution defendants pleading guilty to charges at arraignment began to decrease, and today, in sharp distinction to other misdemeanors, prostitution cases are rarely resolved during arraignment but rather bound over to trafficking court. ${ }^{163}$ The majority of these prostitution defendants are released with a notice to appear in the HTIC, but those with multiple open cases (like Anna), lengthy records, pre-trial release violations, or histories of failures to appear could very well be detained for several days pending appearance in the HTIC, and even after. Among the courts we examined, there was a measure of variability in eligibility for human trafficking court. In Manhattan, for example, only prostitution defendants who have been released at arraignment have their cases adjourned to trafficking court. While this is largely because there is no mechanism to bring incarcerated defendants to $\mathrm{MCC}$, the venue for Manhattan's HTIC, it precludes a class of defendants (those with more complicated records or circumstances) from participating in the court. Similarly, in Queens, the HTIC sees only defendants without multiple charges or extensive criminal records. By contrast, Brooklyn trafficking court takes a wider range of prostitution offenders, including repeat offenders, those with multiple charges, and detention cases. Not surprisingly, the more complicated a defendant's record or circumstances, the more state actors struggle with whether to treat the defendant like a typical misdemeanant or like a victim, an issue discussed below in Subsection II.B.4.

Most of our interviewees lauded centralization because it streamlined communications between prosecutors, defenders, the judges, and service providers. The prosecutors and defenders we spoke with appreciated being able to develop relationships with each other, enabling them to better anticipate how a given case might proceed in court. ${ }^{164}$ Centralization also allows various service providers from nonprofit and

162. See supra note 123 and accompanying text.

163. See Lippman, supra note 9.

164. That said, some of the D.A.'s offices we examined continue to rotate new hires through the HTIC, and some of the judges and defenders explained to us that such attorneys need to be brought up to speed on the unique workings of a human trafficking intervention court. 
public organizations to appear at the same time in a single courtroom. This allows the judge to determine in an efficient manner whether there is space in a program or how a particular defendant is doing in the program. Moreover, the presence of multiple service providers in one place enables judges to connect prostitution defendants with culturally, linguistically, and age-appropriate programs, not just prosecution-run programs ${ }^{165}$ - something the public defenders long desired. Accordingly, centralization simplifies communication.

Centralization also brings the opportunity for other groups interested in human trafficking to be part of the court proceedings. For example, one day when we were observing the Queens HTIC, not only was there an army of service providers, several translators, and the usual court attorneys and staff present, the gallery was also filled with almost as many other interested parties as defendants. That day, spectators included a doctor spearheading a program to meld healthcare for asylum seekers and anti-trafficking efforts, volunteer attorneys from a private law firm, members of Homeland Security's New York asylum office, a member of the Children's Defense Fund, several student interns, and two law: professors (us).

\section{Judicial Style}

Judge Lippman noted during the HTIC rollout that one of the courts' signatures would be specially trained court actors. ${ }^{166}$ At the time we examined the courts, such training had only occurred on a very smallscale and ad hoc basis. ${ }^{167}$ Despite the fact that judges had not yet had extensive training on the dynamics of human trafficking and its relation to prostitution, they embraced the notion that a judge should act differently when adjudicating in the HTIC because the defendants in front of them are likely trafficking victims.

This awareness, however, did not translate into a uniform judicial practice. For example, one of the judges we observed processed ACDs by accepting the attorneys' and service providers' recommendations, asking the defendant whether she "liked" the program (to which all but one defendant replied yes, with the outlier surprising the crowd by forthrightly opining that the program was no good), dismissing the case, and saying "good luck." Another explained that she imagined most defendants, including prostitution defendants, would not appreciate an extended conversation with her, so she tries simply to look defendants in

165. See supra notes $160-61$ and accompanying text.

166. See supra note 123 and accompanying text.

167. See Interview with Toko Serita, supra note 55 (stating that "there is no coordinated training taking place right now"). 
the eye, call them by their names, and speak plainly and respectfully. ${ }^{168}$ She further stated that if the charge includes explicit details, she may simply ask if the defendant has read and understands it rather than read the charge in open court. ${ }^{169}$ In other courts we observed, judges engaged in extended dialogue with defendants about their lives and whether they were improved. One of the more striking instances involved a judge commenting, surely with the intention of being encouraging, that the defendant was doing so much better because she was no longer living in her car. ${ }^{170}$

The judge who detained Anna explained that she deliberately changes her manner of interacting with defendants in the HTIC; in her words: "I think how I, as a judge, relate to those with pending cases is very important to them. Some of them have been treated disrespectfully by people who claim to have authority over them. I try to make this unique court a warmer, friendlier, gentler place." $" 171$ In doing so, she is aware of her very manner of communication: "I make eye contact, smile, and acknowledge the individuals appearing in front of me. I try to convey that I am also there to help them connect them with services they many need." ${ }^{72}$ She considers this judging style to reflect "the paradigm shift in the HTIC." 173 Such judges believe the in-court experience itself is meaningful to defendants and that a denigrating demeanor can further traumatize vulnerable women whereas an encouraging one can help defendants build self-esteem and ultimately improve their lives. ${ }^{174}$

\section{Services}

As noted above, many characterize the default disposition in the HTICs as an ACD premised on the defendant completing a certain number of "sessions," typically five or six, with a designated socialservice provider. The idea is that because prostitution defendants are really victims, they should not be subjected to punishment but rather connected with service providers who can help them rebuild their lives. ${ }^{175}$ Most HTIC stakeholders are quite candid that services are not a panacea, yet most also seem to agree that-unlike earlier programs that perhaps

168. Interview with Felicia Mennin, Presiding Judge, Manhattan Human Trafficking Intervention Court, in New York, N.Y. (Apr. 10, 2015).

169. Id.

170. Transcript of Record at 2, Sealed Proceeding, No. 2014 QN016782 (N.Y. Crim. Ct. June 27,2014 ) (on file with authors).

171. Interview with Presiding Judge, Bronx Human Trafficking Intervention Court, in New York, N.Y. (June 26, 2014).

172. Id.

173. Id.

174. See infra Subsection III.A.2 (discussing "procedural justice" reforms).

175. See Lippman, supra note 9. 
offered classes in STDs or wearing condoms ${ }^{176}$ post-HTIC programming is relevant to defendants' lives, even beneficial. The social workers providing the services explain that the first several sessions with a defendant often involve simply building trust and community with other participants. Thereafter, service providers seek to help defendants cope with trauma, connect them with benefits, and aid them in addressing more concrete needs - perhaps a driver's license or a doctor's appointment. ${ }^{177}$

A good deal has been written on the ways in which therapeutic sensibilities in problem-solving courts legitimate interventions that are more intrusive than those administered in traditional courts - precisely because court mandates are understood not as punishment but as treatment. ${ }^{178}$ Self-reflective court reformers, however, do not feign to draw a hard and fast distinction between court-mandated therapy and other forms of judicial coercion and control. As Julian Adler, Director of Research-Practice Strategies at CCl, explained, "Mandated therapy is neither inherently nor inevitably beneficial to defendants. Nor is the practice somehow immunized against the coercive power ... associated with traditional case processing." 179 Prosecutors in fact condition favorable dispositions upon participating in services. And, as defense attorneys told us and we observed, judges may use the authority of the court and the threat of incarceration to pressure reluctant defendants to accept a treatment-based sentence. ${ }^{180}$

What HTIC stakeholders predictably debate is whether coercion for the sake of treatment is a good or bad thing. Defense attorneys aim to protect their clients from the lack of agency, inconvenience, and even material detriment they experience by being compelled to comply with mandates. They believe their clients, as victims, are not culpable for an underlying crime that would justify court control and that their clients are re-victimized by judicial acts of authority and mandated participation in court-ordered programs. A public defender in the Bronx describes how the judge's order mandating services affected one of her clients:

176. See Victoria Malkin, The End of Welfare as We Know It: What Happens When the Judge Is in Charge, 25 CRITIQUE ANTHROPOLOGY 361, 381 (2005).

177. Interview with Miriam Goodman, Assistant Dir. of Anti-Trafficking \& Trauma Initiatives, Ctr. for Court Innovation, in New York, N.Y. (June 24, 2014).

178. See Malkin, supra note 176, at 362 (discussing the different types of treatment received by those arrested for prostitution). See generally Jason Schnittker, The American Drug Court Movement, 80 SOCIAL FORCES 1406, 1407 (2002) (reviewing JAMES L. NOLAN JR., REINVENTING Justice: The American Drug Court Movement (2001)).

179. Interview with Julian Adler, Dir., Ctr. for Court Innovation, in New York, N.Y. (Apr. 11, 2014).

180. See Malkin, supra note 176, at 362 (noting that in problem solving courts "[t]he defendant's appearance in court is the beginning of an overtly coercive process where the threat of incarceration is used to encourage him or her to take this opportunity to change"). 
Last week, a client of mine walked out of the courtroom after her court appearance extremely upset. The judge was concerned, called me up to the bench, and said, "Whatever it is your client needs - be it food, shelter, clothing - make sure she gets help." When I met my client outside the courtroom, she explained to me that she was upset about the judge saying that if she didn't complete services she would get 15 days jail. She was offended by the way the judge had talked to her. That is the problem: the judge means well, but when participation in services is coerced with an arrest and the threat of jail time, the client is disempowered, and the good intentions backfire. ${ }^{181}$

Others stakeholders explicitly argue that it is normatively desirable to use the criminal justice system to incentivize defendants to engage in selfhelp. For example, consider this exchange between Kristine Herman, Strategic Initiatives Specialist at Brooklyn Defender Services and Councilperson Lewis Fidler at a City Council hearing to discuss how the HTICs address the needs of New York City's homeless youth:

Kristine Herman: [W] hen we use the power of the court to force people into services, we're actually continuing to revictimize them ....

Chairperson Fidler: I don't know that I agree with that so fully; that you'd continue to victimize them. Sometimes you have to compel people to help themselves. Certainly that's the philosophy of the Bloomberg Administration.... [T]here may be some people who come into this [court] . . . [who have declined help] and gone back to doing the same destructive behavior; ... [they] might need the incentive of listen, you know, you've got to stop this. You need to get help that you know, the criminal justice system can provide. ${ }^{18}$

Perhaps more vexing than the coercive nature of treatment mandates for a population generally understood as having experienced victimization and trauma is how to ensure that services are not treated by prosecutors or understood by defendants as punishment itself. Judges and prosecutors, for example, discussed with us why the default HTIC condition only involves five sessions (compared to, for example, twenty-

181. Interview with Zoe Root, Attorney, Bronx Defs., in New York, N.Y. (June 26, 2014).

182. Oversight Transcript, supra note 57, at 161-62 (statements of Kristine Herman, Policy Analyst, Brooklyn Def. Servs., and Lewis A. Fidler, Chairperson, Comm. on Youth Servs.). 
seven DV classes). ${ }^{183}$ They explained that five represented a compromise between the "disposable" past of no sessions and multiple mandated meetings that can overburden defendants, regardless of the number of sessions that might be clinically appropriate given a person's particular context and needs. ${ }^{184}$ That is, court participants recognize that sessions, although meant to be therapeutic, are a form of punishment that must therefore be proportional to the underlying crime. And this form of penal treatment can ultimately include incarceration when, for example, a defendant gets rearrested before completing the service mandate within the prescribed time-frame. ${ }^{185}$ Often prosecutors (and sometimes judges) respond to failures to complete the service mandate by tacking on more sessions; defense attorneys, in turn, argue for fewer sessions. And hence exists the phenomenon of adversarial bargaining over "beneficial" services.

\section{Defendants with Records or Multiple Charges}

As evidenced by Judge Lippman's statements ${ }^{186}$ and the sentiments of. many of the HTIC architects, the HTICs presume that prostitution defendants' criminal acts are products of gender violence and duress and that legal actors in the HTICs should have knowledge of the particular "dynamics" of sex trafficking. ${ }^{187}$ This entails not only recognizing that prostitution defendants are physically and emotionally coerced but also the understanding that the dynamic makes it difficult for women to leave the life, creating a high likelihood of recidivism. ${ }^{188}$ Thus, for many of our interlocutors, a defendant's long rap-sheet simply further confirms victimization. As Judge Serita explained, "Recidivism is something that we address all the time in these trafficking intervention courts because it

183. See Cohen \& Gruber, supra note 90 (discussing DV diversion); see, e.g., Domestic Violence Classes, GA. FAM. CRISIS SOLUTIONS, http://www.gfcscc.com/substance-abuse-classes (requiring no less than 24 classes). In Colorado, DV sessions are indefinite and subject to board approval. See Denver BAR Ass'N, COLO. DOMESTiC Violence BenchiooK (2011), http://www.denbar.org/repository/DV\%20Benchbook\%20Final\%2010_2011.pdf?ID=20475.

184. See, e.g., Interview with Kim Affronti, Queens Assistant Dist. Attorney, in New York, N.Y. (June 24, 2014).

185. See Transcript of Record at 2, Sealed Proceeding, No. 2014BX030650 (Bronx Cty. Crim. Ct. June 8, 2014) (on file with authors).

186. Lippman, supra note 9.

187. Lippman, supra note 9. See supra Sections I.B-C.

188. See Oversight: How Do the Human Trafficking Intervention Courts Address the Needs of New York City's Runaway and Homeless Youth Population?: Hearing Before the Committee on Youth Services, 2010-2013 Sess. 4 (N.Y.C. Council 2013) [hereinafter Oversight Testimony] (testimony of Kim Affronti, Deputy Chief, Criminal Court Bureau, Queens Cty. Dist. Attorney's Office), http://legistar.council.nyc.gov/Legislation.aspx ("Recognizing that, like drug addiction, relapse may be part of the process, the Queens Human Trafficking Intervention Program often will give such individuals another opportunity...."). 
is the nature of the phenomenon. It is the nature of the business; it's the nature of trafficking." 189 In addition, many recognized that court interventions are themselves unlikely to deter trafficking, given the nature of the relationships involved. One prosecutor, for example, candidly admitted, "We know on average that it takes four to five times to actually want to accept the program and want to accept the treatment and want to move forward." "Moreover, many stakeholders believe that even defendants who wish to exit prostitution struggle to do so, not only because of coercion, but also because of the lack of basic necessities like shelter.

Nevertheless, the HTIC philosophy that regards prostitution defendants as coerced victims who are not responsible for recidivist conduct runs up against the structure of criminal prosecution, which necessarily views recidivism as an important, if not the most important, factor in determining pre-trial conditions, plea offers, and sentences. The bail process, unlike sentencing or problem-solving adjudication, does not have a mechanism for taking into account the fact that the defendant's crimes are a result of her marginalized or coerced status. Rather, the bail decision is about determining the likelihood that the defendant will flee or reoffend while on release and weighing those decisions against the hardships bail would create for the defendant. ${ }^{191}$ It has little to do with whether the defendant is factually innocent and even less to do with whether the defendant is the "real" victim. Given this, the probability of release on bail can be inversely related to evidence of trafficking (which can take the form of lengthy records, open cases, and repeat offenses). Moreover, even when state actors acknowledge that long prostitution records are evidence of victimization rather than criminality, incarceration can still result. Anna, for example, was kept in pretrial detention to protect her from her abusive intimate partner. ${ }^{192}$ In some courts defendants with complex records and multiple open cases are simply ineligible for HTIC. ${ }^{193}$

A similar issue arises during plea negotiations. In non-prostitution misdemeanor processing, favorable alternative dispositions are often reserved for first-time offenders. However, many HTICs officials, trained in the dynamics of trafficking, recognize that multiple offenses indicate prolonged victimization. In this view, it should not matter whether it is

189. Interview with Toko Serita, supra note 55.

190. Telephone Interview with Anonymous Brooklyn Assistant Dist. Attorney, (July 11, 2014).

191. N.Y. CRIM. PROC. LAW $\$ 510.30$ (McKinney 2016) (identifying factors and criteria upon which a bail determination can be made, which include a defendant's criminal history and previous record of appearing in court when required but do not contemplate victimhood or recognize the notion of a victim-defendant among the enumerated criteria).

192. See supra Section II.A.

193. See supra Subsection II.B.1. 
the defendant's first or fiftieth prostitution case-the disposition should be the same. Indeed, some prosecutors and judges we spoke to represented that they would keep offering an ACD and services no matter how many times a defendant came back with new charges. However, this does not always or even generally happen. As it turns out, it is difficult for court actors to resist the inherent criminal law logic that first-timers should be treated differently than repeat players. For example, Judge Serita, who candidly explained that she struggles with the fact that women engaged in prostitution are criminally charged, ${ }^{194}$ recognized the difficulty repeat offenders pose:

Obviously there is a tension with rearrests and recidivism.... Older defendants sometimes have 15 criminal convictions. What do you do then? ... If somebody says to me, for example, "listen, I have $\mathrm{x}$ number of convictions but I've never been given the opportunity for a program," that's something I'm interested in. . . . Do you offer a jail sentence or do you offer this person an opportunity to explore that? I think these prostitution cases are incredibly difficult, incredibly challenging, and very complex because there is no right answer. ${ }^{195}$

For prosecutors, the question is perhaps even more fraught because they worry that failing to progressively ratchet up punishment with each re-arrest might have the effect of encouraging prostitution within their jurisdictions. Queens Prosecutor Kim Affronti discussed declining to give services to a young woman from California who she thought was trafficked into prostitution in New York: "Normally I would say plea to the charge but really ... to have been arrested so many times for prostitution in so many different states. Obviously she's a victim." 196 She continued: "But still, she just has so many arrests, so I discussed it with [the public defender], and I said that I will give her a disorderly conduct and time served and she can go back to California."197 She further told the defender, "[This is her] first arrest in Queens and it better be the last because I don't want people coming into Queens [thinking], 'Oh you get a good disposition in Queens." 198 In another jurisdiction, prosecutors insist that defendants sign waivers explicitly allowing the D.A.'s Office the right to access its own records of prostitution cases that were resolved with an ACD and sealed. The D.A.'s Office defends this decision on the grounds that it helps D.A.s craft better service mandates; defense

194. See Cohen \& Gruber, supra note 90 (quoting Judge Serita and proceeding to explore some of her nuanced views on the social role of the HTICs).

195. Interview with Toko Serita, supra note 55.

196. Interview with Kim Affronti, supra note 184.

197. Id.

198. Id. 
attorneys, however, suspect they want to keep track of recidivists to increase penalties in the event of a future arrest or for intel purposes.

Other judges and prosecutors break from the HTIC default of ACD and services, not because of repeat offenses, but because the prostitution defendant's record shows evidence that she committed other types of crimes. Drug charges are a common problem. Some judges and prosecutors suggest that exposure to controlled substances is part of the cycle of domination and control within the trafficking dynamic and that drug addiction can be understood as a common response to trauma. Others, however, are less sympathetic. For example, in one HTIC case in the Bronx, a defendant with a misdemeanor drug charge was sent to the HTIC because she had a history of prostitution as a young woman. Once there, the court referred her to a service provider, and she worked with them for a longer period of time than most HTIC defendants who receive ACDs. However, the prosecution refused to grant her an ACD, or even allow her to plead guilty to a lesser offense, because the charge involved drugs, not prostitution. ${ }^{199}$

Likewise, in the Brooklyn HTIC, Judge Hecht made clear that defendants with current or past drug charges did not merit a more favorable disposition simply because they also had prostitution charges. ${ }^{200}$ For example, in a case where an HTIC defendant had three separate cases (one for prostitution and two for drugs), the prosecutor and defense attorney agreed that she should be released to outpatient drug treatment. But the court refused:

I don't know why putting something in AP8 [trafficking courtl should mean that the policy of [Operation] Spotlight Tan initiative aimed at identifving and imposing heavier sentences on persistent misdemeanor offenders $7^{201}$ no longer applies-vour policy of MBTC [inpatient treatmentl no longer applies, iust because one of the three cases has an AP8 eligible charge. ... I don't think I should take non-AP8 Inonprostitution] cases. I think the persistent misdemeanant cases

199. Transcript of Record at 6, Sealed Proceeding, No. 2014BX030715 (N.Y. Crim. Ct. Oct. 2,2014 ) (on file with authors).

200. Id. at 9-12.

201. See Press Release, N.Y.C. Office of the Mayor, Mayor Michael R. Bloomberg Announces Operation Spotlight: New Initiative Focuses on Persistent Misdemeanants (May 21, 2002), http://tinyurl.com/zrq9lpl; see also Christine Sisario, Improving Outcomes Through Better Data Tracking: The Use of Technology in Problem-Solving Courts and Beyond, in NAT'L CTR. For State Courts, Future Trends In STATE COURTS 2009, at 92, 95 (2009) (indicating that Operation Spotlight leads to "an increase in the percentage of eligible defendants detained on bail and receiving jail sentences"). 
and the 220.03 [drug cases] should iust stay in their parts, and I will just deal with AP8 cases. $^{202}$

The prosecutor on the case attempted to explain that AP8 involves a different approach:

With all cases that are in AP8, we are attempting to address an issue of prostitution and trafficking which has many, many spokes - it's a wheel with manv, many spokes. Drugs often are the reason why a person is engaged or being trafficked or prostituted so in that case taking all of the cases together in this part is more than appropriate. it allows us to comprehensively assess each and every client and provide them with the most comprehensive care .... Sending her to iail. we are not going to incarcerate ourselves out of a drug or prostitution or trafficking problem. ${ }^{203}$

Judge Hecht sentenced the defendant to thirty days in jail on the prostitution case that day, but refused to release her or sentence her to anything less than a year, the maximum sentence, on the two remaining drug cases. Those cases were continued in a court outside of the HTIC, where the defendant was eventually sentenced to six months in jail.

In addition to drug offenses, people arrested for prostitution offenses not infrequently have other criminal charges. Indeed, given the pervasive nature of quality-of-life, or public-order, policing in New York City, arrests for minor offenses are common. Within the HTIC system, the treatment of prostitution defendants with other non-prostitution charges tends to vary. ${ }^{204}$ Certain HTIC prosecutors and judges are generally willing to grant defendants charged with non-prostitution misdemeanors the default $\mathrm{ACD}$ and service sessions, as long as the non-prostitution offenses do not involve violence. The Queens HTIC is a good example. For others, this is a hard sell. Consider once again the Brooklyn HTIC, particularly relevant here because it, unlike other HTICs, often sees "complicated" prostitution defendants. ${ }^{205}$ In one case, an HTIC defendant with mental-health and substance-abuse issues had an open misdemeanor "criminal mischief" charge pending in another court. The prosecutor and defender agreed on a disposition that involved outpatient drug and psychological treatment through the Center for Community Alternatives

202. Transcript of Record at 4, Sealed Proceeding, No. 2014KN084262 (Kings Cty. Crim. Ct. Nov. 19, 2014) (footnote added) (on file with authors).

203. Id. at 6.

204. Recall that Manhattan and Queens HTICs see fewer prostitution defendants with other misdemeanor charges. See supra Subsection II.B.1.

205. See supra Subsection II.B.1. 
(CCA), a service provider that frequently works with defendants. ${ }^{206}$ In resisting the plea deal and urging in-patient treatment, Judge Hecht had the following exchange with the CCA social worker:

The Court: So even though she has three open cases, two of them are "A" misdemeanors, one involves mischief, you don't believe that in-patient treatment is necessary?

Ms. Pakisima: No, your Honor, not at this time.

The Court: ... Criminal mischief]] obviously is a crime with a victim, so these are not simply drug possession cases. So you're aware of that and that's still your recommendation?

Ms. Pakisima: Yes. ${ }^{207}$

Upon the social worker's assurance that CCA would report any noncompliance with the program to the court "immediate[ly]," the judge ultimately went along with the program urged by the prosecutor, defender, and social worker. ${ }^{208}$

Some court actors draw the line at any conduct that victimizes others, even if the victimization involves only theft of or damage to property and not violence. ${ }^{209}$ For example, prosecutor Hannah Freilich explained how she would deal with a prostitution defendant with multiple charges: Depending on the nature of the defendant's other crime and the extent to which there is a victim, she elaborated, "it would almost be as if he or she is two different people." ${ }^{.10}$ That is, she would consider the defendant a victim for the prostitution offense, but for other offenses, "the focus would have to be on that victim before the defendant-victim." 211 Similarly, a prosecutor very committed to HTIC courts and the notion of prostitution defendants as victims nonetheless explained that she drew the line at defendants with violent criminal records. ${ }^{212}$

206. See generally CTR. FOR CMTY. ALTERNATIVES, http://www.communityalternatives.org/ (last visited May 18, 2016).

207. Transcript of Record at 7, Sealed Proceeding, No. 2014KN026021 (Kings Cty. Crim. Ct. Nov. 19, 2014) (on file with authors).

208. Id.

209. Id. (noting that the defendant "has 50 cycles in her rap sheet including three convictions in the last year for drug related offenses, criminal mischief, obviously is a crime with a victim, so these are not simply drug possession cases").

210. Interview with Hannah Freilich, supra note 134.

211. Id.

212. Telephone Interview with Anonymous Brooklyn Assistant Dist. Attorney, supra note 190. 


\section{Evidence of Trafficking}

Finally, we arrive at the issue of the intersection of prosecution and human trafficking. As we suggest above, there is remarkably little talk of trafficking in the human trafficking courts. Although the presumption of trafficking in prostitution cases appears to have changed the default disposition in prostitution cases (from conviction and time-served to $\mathrm{ACD}$ and sessions), many defense attorneys told us that the risks of disclosing a particular defendant's trafficking victimhood often outweigh the rewards.

In theory, prosecutors are willing to dismiss outright cases of trafficked victims, but in practice prosecutors tend to dismiss only when the woman is willing to share and document the specifics of the trafficking - something few are willing to do. According to defense attorneys, defendants worry that disclosure may place them in danger and that law enforcement may try to coerce their cooperation. Moreover, as in Anna's case, disclosure of evidence of trafficking-for example, that she was trying to leave her intimate partner-can have the effect of ratcheting up services and increasing administrative burdens on the defendant. ${ }^{213}$ Remarkably, after Anna's unusually lengthy jail stint and completion of her fifth and final service session, prosecutors still declined to resolve her three open cases. ${ }^{214}$ According to Anna's attorney, "The D.A. is like, 'Well I just want to see if she's doing well. I want to see her connected to mental health services. I want to see her do this and that.' ... [Disclosing vulnerability] keeps the case open longer. It requires more of the client. It shortens the calendar appearances so they're literally coming to court almost every week. I mean it's too much."215

Further, disclosure can lead judges and prosecutors to use incarceration as a way of mandating safety, particularly in instances where there is concern about the defendant's ability to make good choices for herself. Consider another example that occurred in a combined session of the HTIC and drug treatment court. In this case, the defendant agreed to participate in residential drug treatment, but the treatment court staff struggled to secure appropriate placement, given that the defendant was pregnant. After her baby was born, and removed from her care, she appeared in court for a regular appearance, as the treatment team continued to work on a placement. ${ }^{216}$ The defendant had previously disclosed to her treatment team a history of having been trafficked, most

213. See supra Section II.A.

214. See supra Section II.A.

215. Interview with Aisha Lewis-McCoy, supra note 129.

216. Transcript of Record at 2, Sealed Proceeding, No. 2011 QN053666 (Queens Cty. Crim. Ct. Jan. 15, 2015) (on file with authors). 
recently by an intimate partner. At the hearing, concerns arose about where she would continue to live awaiting program placement. Specifically, the prosecutor stated: "I do not want to see Ms. F going back to her ex-boyfriend, whatever she thinks he is. In my eyes, that's the person that's exploiting her and that's just not a good situation, Judge. I am going to ask that she be[] remanded [to jail]."217

The very fact that this HTIC defendant had disclosed trafficking became the specific grounds on which prosecutors sought to put her in jail. She had not committed any additional crime, and had appeared in court when required. The prosecutor and judge's knowledge of Ms. F's past experiences and abusive relationship set her incarceration in motion. The judge sent the defendant to jail until her next court appearance, echoing the prosecutor's analysis: "She certainly cannot go back to her ex-boyfriend who's abusive so that is not an option ...."218 Before her incarceration, the defendant had appeared for all her court dates. However, when the judge finally released her from "protective" detention, the defendant never returned to court.

Finally, even when disclosure does not risk incarceration, many defendants simply feel uncomfortable about discussing the intimate details of their victimization with the people criminally prosecuting them. Again, Anna's defense lawyer: "[A]ttorney-client [trust] takes some time to build up, and no one's going to say anything to me if the first thing I'm going to do is say, 'Yes nice to meet you, please go tell your story to this [prosecutor]." 219 Perhaps anticipating some of these hurdles, court reformers stress that the benefits of the HTIC system should not turn on specific evidence of trafficking. Indeed, prostitution-abolitionist feminists purposefully argued for a decontextualized, universalizing approach to victimhood. In Judge Kluger's words:

[W]e don't make an assessment on each person who's charged that you were or were not trafficked. . . . Anyone who comes into these courts services charged with prostitution or prostitution-related offenses are able to get the services and get the favorable resolution that we hope will come out of this. There is no artificial bar that says well, we don't think you were trafficked ... 220

Despite this description, defendants who are unwilling to offer specific evidence of trafficking may not receive the most favorable resolutions.

217. $I d$.

218. Id.

219. Interview with Aisha Lewis-McCoy, supra note 129.

220. Oversight Transcript, supra note 57, at 40 (statement of Judy Kluger, Judge, N.Y.C. Criminal Court). 
At the same time, prosecutors uniformly explain that they do not condition plea offers on HTIC defendants' cooperation against traffickers. They put ACDs and service mandates on the table, not to induce cooperation, but to reflect the quasi-victim status of the defendants and the problem-solving nature of the court. ${ }^{221}$ Still, prosecutors hold out hope that defendants receiving ACDs and services will decide to leave traffickers and cooperate with authorities against them. Indeed, prosecutor Hannah Freilich expressed a wish that defense attorneys would "empower the defendants" by encouraging them to talk with her. ${ }^{222}$ "If our goal is to eliminate trafficking," she explained, "the only way we can do that is by [the defendant] telling us what's going on-who the traffickers are." ${ }^{223}$ For her, this special mandate distinguished the HTICs from other problem-solving courts designed simply to "treat" defendants. ${ }^{224}$ In her words: "What is the goal of a 12-step drug treatment program? To cure someone of their drug habits. What's the goal here? Not to get this particular individual from not committing prostitution, but globally to eliminate the trafficking and the exploitation of these women."225

In sum, there are many complexities and contradictions in the HTIC. system that reflect its ambitions to be both revolutionary and pluralist. The system seeks to help destigmatize prostitution defendants by publicizing the serious social, emotional, and economic constraints they face and thus to help them shed the label of degenerate criminal. At the same time, at least some of the actors in the court want prostitution defendants to cooperate in trafficking investigations and prosecutions and to create a world in which prostitution simply does not exist. Likewise, the court has the unenviable task of trying to satisfy diverse stakeholders with very different positions on the legality of sex work, the costs of criminalization, and what prostitution defendants want or need. Court reformers seek buy-in from prosecutors (ostensibly representing "community will"), who continue to cite the need for police to clean up the streets, ${ }^{226}$ and from defenders, who harbor a deep distrust of policing and prosecution. Court reformers also hope to satisfy new abolitionists,

221. Prosecutors and law enforcement do capitalize on HTIC structure in other ways. The centralization feature of HTICs allows prosecutors and detectives to keep tabs on repeat offenders and the people accompanying them and talk to the men (presumed traffickers) in the gallery.

222. Interview with Hannah Freilich, supra note 134.

223. Id.

224. Id.

225. Id.

226. See, e.g., Telephone Interview with Anonymous Brooklyn Assistant Dist. Attorney, supra note 190 ("We have a duty to do enforcement. No one really wants prostitution in their community. It draws a lot of other bad attendant issues such as drugs, such as gangs, such as shootings-so we do have a duty to look at those crimes and to protect the community."). 
who see themselves as warriors against an international slave trade, and social workers and others more concerned with addressing individual and social trauma.

Given these complex and clashing goals and constituencies, Part III takes a critical look at the HTICs and assesses their practical successes and limitations in light of larger questions of state authority, distributive justice, and gender equality.

\section{Toward A Penal Welfare System}

In contrast to the tough-on-crime decades of the $1980 \mathrm{~s}$ and $90 \mathrm{~s}$, today many experts and policy makers denounce "mass incarceration."227 As such, the concept of criminal court "decarceration" has become increasingly popular. ${ }^{228}$ Similarly, progressive reformers, including those affiliated with the HTICs, call for "procedural justice" to create a more dignified in-court experience, regardless of outcome. ${ }^{229}$ This Part discusses whether and how the HTICs have in fact benefited people

227. As Professor Gruber explains:

Today, the liberal critique of mass incarceration and the American penal state, an institutional critique, is well-trodden academic territory. Some object on human rights grounds that the United States is an outlier among industrialized countries in its punitiveness. Others connect the ideology of crime control to a neoliberal political philosophy that is inherently inhospitable to marginalized members of society. Critical race theorists have demonstrated how the growing carceral state has harmed communities of color and other subordinated groups.

Aya Gruber, Murder, Minority Victims, and Mercy, 85 U. Colo. L. Rev. 129, 171 (2014) (footnotes omitted); see also MiCHELlE ALEXANDER, THE NEw JIM Crow: MASS INCARCERATION IN THE AGE OF COLORBLINDNESS 2 (2010); PAUL BUTLER, LET'S GET FREE: A HIP-HOP THEORY OF JUSTICE 20, 45-46 (2009) (problematizing mass incarceration); Frank O. Bowman, III, Murder, Meth, Mammon, and Moral Values: The Political Landscape of American Sentencing Reform, 44 WASHBURN L.J. 495, 505 (2005) ("[T] he human and economic costs of the American experiment in mass incarceration have been high."); Marie Gottschalk, The Long Reach of the Carceral State: The Politics of Crime, Mass Imprisonment, and Penal Reform in the United States and Abroad, 34 L. \& Soc. INQUIRY 439, 450-51 (2009); Dorothy E. Roberts, The Social and Moral Cost of Mass Incarceration in African American Communities, 56 STAN. L. REV. 1271, 1298-99 (2004); Jonathan Simon, Introduction: Crime, Community, and Criminal Justice, 90 CALIF. L. Rev. 1415, 1417 (2002) (linking increased securitization to "sprawl, traffic congestion, desertion of public spaces and institutions, and a national epidemic in childhood obesity"); Andrew E. Taslitz, The Criminal Republic: Democratic Breakdown as a Cause of Mass Incarceration, 9 OHIO ST. J. CRIM. L. 133, 133 (2011); Anne R. Traum, Using Outcomes to Reframe Guilty Plea Adjudication, 66 FLA. L. REV. 823, 825 (2014). Alice Ristroph sums it up: "The American criminal justice system is the pride of no one." Alice Ristroph, Criminal Law in the Shadow of Violence, 62 ALA. L. REV. $571,610(2011)$.

228. For an overview of this position, see generally Allegra M. McLeod, Decarceration Courts: Possibilities and Perils of a Shifting Criminal Law, 100 GeO. L.J. 1587 (2012).

229. See infra Subsection III.A.2. 
engaged in prostitution through jail diversionary sentences, procedural reform, and service provision. It then analyzes whether the HTICs nonetheless sustain prostitution criminalization and prevent other avenues of reform, such as non-criminal service provision or labor regulation. Finally, it considers how the HTICs reflect and reinforce particular assumptions about sex work and gender. Because of these assumptions, we argue, the HTICs are unlikely to catalyze broader criminal justice reforms that benefit other defendants who are also victims of individual and structural violence, even prostitution defendants who commit non-prostitution crimes.

\section{A. The Limits of Reform from Within: Decarceration and Procedural Justice}

At the outset, we note that in assessing HTIC reforms, we primarily consider whether reforms benefit prostitution defendants, the group publically recognized as the intended beneficiaries. That is, we concentrate less on, for example, whether the HTICs have reduced domestic prostitution or made a dent in the global trafficking trade. Even confined to this analysis, we recognize that whether something is a harm or benefit depends on the person, context, and available alternatives. Nevertheless, our research provides some insight into what has changed and whether it is for the better.

\section{Decarceration}

Many HTIC proponents today describe the court as part of a larger "alternative to incarceration" movement. ${ }^{230} \mathrm{CCI}$ director Courtney Bryan, for example, explains that the HTICs are part of an effort to "minimize the entrenchment in the criminal justice system through alternatives to incarceration or alternatives to detention."231 In several ways, the HTICs reflect this aspiration, substituting services for jail in most cases. ${ }^{232}$ The HTICs also are distinct from other instances of decarceration because they provide better dispositions (ACDs in lieu of misdemeanor convictions) for prostitution defendants, and thus appear to

230. See, e.g., Toko Serita, In Our Own Backyards: The Need for a Coordinated Judicial Response to Human Trafficking, 36 N.Y.U. REv. L. \& SOC. ChaNGE 635, 635 n.5 (2012) ("The HTIC provides alternatives to incarceration for people arrested on prostitution-related charges, premised upon the understanding that many of the defendants are victims of sex trafficking."). See generally Mary D. Fan, The Political Climate Change Surrounding Alternatives to Incarceration, 38 HUM. RTS. 6, 6-7 (2011); Developments in the Law-Alternatives to Incarceration, 111 HARV. L. REV. 1863 (1998) (discussing the alternatives to incarceration movement).

231. Interview with Courtney Bryan, supra note 88 .

232. See Serita, supra note 230 , at 659. 
recognize that a criminal conviction, whether or not accompanied by incarceration, is a serious harm. ${ }^{233}$ The HTICs have thus coincided with both a dramatic increase in dismissals of prostitution charges, primarily via $\mathrm{ACD},{ }^{234}$ as well as a decrease in prostitution defendants sentenced to jail. ${ }^{235}$

Few could disagree with the notion that from the perspective of defendants, a dismissal is better than a conviction, and liberty is better than jail. But decarceration within the HTICs is not that simple. The court and its participants must manage dual roles as caring protectors of trafficking victims and arbiters of laws against criminals. How they do so limits the decarceral potential of the courts. HTIC architects justify leniency as reflecting the true victimhood status of prostitution defendants, who presumptively suffer gender violence. ${ }^{236}$ As a victimhood-based maneuver, rather than an anti-incarceration maneuver, the HTICs must necessarily be lenient toward defendants who are in fact victims, but it does not have to extend the same courtesy to "real" defendants. ${ }^{237}$ Maintaining this line between victim-defendants and real defendants is quite difficult in practice. HTIC proponents and personnel paint with a broad brush and simply presume that prostitution defendants are victims. ${ }^{238}$ However, as we have seen, this presumption does not always prevail when the defendant-victim's lengthy record, past failures to appear rearrests, or other charges suggest to the court that she has engaged in "real" criminal behavior. ${ }^{239}$

233. See supra note 88 and accompanying text.

234. In 2008, $13 \%$ of closed prostitution cases in New York City were resolved with an ACD. N.Y. Div. of Criminal Justice Servs., supra note 14 . That number increased to $47 \%$ in 2014 . Id.

235. In 2014, the percentage of prostitution defendants sentenced to jail as resolution of their criminal charges in New York City fell to $7 \%$ from $20 \%$. N.Y. Div. of Criminal Justice Servs., supra note 152 . Overall incarceration has likely fallen as dismissals have increased, but this is not to say that overall detention has decreased because the courts do not keep records of pre-trial detention time.

236. See supra notes $87-90$ and accompanying text. For a discussion of "sex exceptionalism," see generally infra Section III.C.

237. And, in fact, the HTIC program contemplates harsher sanctions for the "real criminals"- buyers and traffickers. See infra notes 259-61 and accompanying text. The picture of where a seller of sex falls on the spectrum of victim to criminal, even regarding the sex itself, is not so clear. One prosecutor explained that the D.A.s often have to figure out whether certain prostitution defendants are victims, traffickers, or hybrids. Telephone Interview with Anonymous Brooklyn Assistant Dist. Attorney, supra note 190.

238. See supra note 220 and accompanying text.

239. "Real" criminal behavior can extend to the very act of prostitution, if there are children involved. In one case, a judge knew from a previous case that a prostitution defendant had an eight-week-old child. Transcript of Record at 2, Sealed Proceeding, No. 2014KN004635 (Kings Cty. Crim. Ct. Jan. 29, 2014) (on file with authors). From that, he concluded that the defendant must have somehow neglected the infant simply because she had continued to engage in prostitution. Id. Despite the fact that there were no allegations of neglect, or that the child was 
Moreover, as our description makes clear, the HTICs are by no means an alternative to criminal processing. The price for liberty and a disposition that does not forever mark the defendant is mandated services. To be sure, defense attorneys agree that many defendants view services as a benefit or at least a small price to pay for avoiding conviction and jail. Some defendants, however, actually elect the old default of conviction and time served over ACDs with conditions (even though it comes with a substantial court fee), ${ }^{240}$ because they do not want services or know they cannot complete services. Indeed, the fact that it is a criminal court mandating services means continuing court involvement and monitoring, where the defendant must make regular and multiple appearances, potentially extending the case well past the period it would otherwise take to complete five service sessions. ${ }^{241}$ Moreover, criminal court mandates are secured with the threat of a criminal record and incarceration, and accordingly every "connection" to services carries the risk of punishment. ${ }^{242}$ For this reason, defendants prefer dismissal without mandatory services, and defense attorneys routinely bargain. down even concededly beneficial services. ${ }^{243}$ To the extent proponents ${ }^{*}$ argue that criminal management is nonetheless justified because it provides welfare or reduces recidivism, ${ }^{244}$ the HTICS are not primarily about decarceration and may in fact sustain criminalization in other ways.

\section{Procedural Justice}

A slightly different reform-from-within idea is that reformers should direct their efforts toward making court processes more palatable to those subject to court authority, in this case prostitution defendants. The theory, attributable in large part to the empirical work of Yale Law Professor Tom R. Tyler, is that by improving the in-court experience, individuals will regard the court as more legitimate and their experiences

uncared for at the time of the defendant's arrest, the judge assumed that the baby had been left home alone. Id. Calling this speculative uncharged conduct a "serious allegation," the judge mandated the defendant to extensive parenting classes in addition to the required AP8 counseling sessions. Id.

240. In New York State, anyone convicted of a felony, misdemeanor, or violation offense, faces mandatory fees and surcharges at the time of sentencing. N.Y. PENAL LAW $\S 60.35(1)$ (a) (McKinney 2016). The surcharge and fees owed upon a misdemeanor conviction are $\$ 200$, and upon a violation conviction, $\$ 120$. Id.

241. See supra note 215 and accompanying text.

242. See supra note 185 and accompanying text.

243. See supra notes $185-86$ and accompanying text.

244. See infra notes 296-305 and accompanying text (discussing the view that the way to tackle the prostitution problem is by arresting prostitution suspects but not saddling them with convictions). 
in it as more satisfactory, regardless of outcome. ${ }^{245}$ In addition, empirical evidence attests that such procedural changes improve the odds that individuals will follow court mandates. ${ }^{246}$ New York court reformers have deployed these sociological findings to justify problem-solving courts. ${ }^{247}$ Reformers, citing Tyler, identify several court procedures embraced by the HTICs that purportedly leave defendants more satisfied with the judicial process: giving defendants a voice, treating defendants with respect, and garnering defendants' trust by listening and explaining outcomes. $^{248}$ Yet a vast amount of literature and experience with alternative criminal justice experiments demonstrates that reform from within is exceedingly difficult to achieve - the master's tools simply may not be designed to dismantle his house. ${ }^{249}$ Incremental changes to make

245. Tom R. Tyler, Procedural Justice and the Courts, 44 CT. REv. 26, 27 (2008) ("For example, all parties have the opportunity to present their story and to have it considered by the relevant authorities."); Tom R. Tyler \& Kenneth Rasinski, Procedural Justice, Institutional Legitimacy, and the Acceptance of Unpopular U.S. Supreme Court Decisions: A Reply to Gibson, 25 Law \& SoC'y Rev. 621, 622 (1991); Tom R. Tyler, What Is Procedural Justice?: Criteria Used by Citizens to Assess the Fairness of Legal Procedures, 22 LAW \& SOC'Y REV. 103, 117 (1988). See generally E. Allan Lind \& TOM R. TYleR, THE SOCIAL Psychology OF Procedural Justice (Melvin J. Lerner ed., 1988); TOM R. TYler, Why PeOple Obey THE LAW (1990).

246. See Tyler \& Rasinski, supra note 245 , at 627.

247. See, e.g., M. SOMJEN Frazer, THE IMPACt of THE COMmuntTy COURT Model on

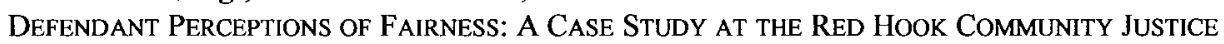
CENTER 5 (2006) http://www.courtinnovation.org/sites/default/files/Procedural_Fairness.pdf; Emily Gold lagratta \& Phill Bowen, Criminal Justice All., To Be Fair: Procedural FAIRNESS IN COURTS 1 (2014), http://criminaljusticealliance.org/wp-content/uploads/ 2015/02/TobeFair.pdf (seeking to "[s]ituate] procedural fairness within the wider discussion about the legitimacy of criminal justice institutions"); Emily Gold \& Melissa Bradley, The Case for Procedural Justice: Fairness as a Crime Prevention Tool, COMMUNITY ORIENTED POLICING SERVICES (Sept. 2013), http://cops.usdoj.gov/html/dispatch/09-2013/fairness_as_a_crime_preven tion_tool.asp ("The Cen «ar for Court Innovation--in partnership with the U.S. Department of Justice's Bureau of Justice Assistance and the National Judicial College - has spent the past two years developing and piloting a curriculum to help judges and other court players to translate the precepts of procedural justice into daily practice.").

248. This procedural-justice theory has also been lauded as the solution to problems endemic to policing. For example, William Bratton has recently sought to replace broken windows policing with community interfacing, noting the need to change from "an overarching focus on police activity [i.e. arrests], to an emphasis on collaborative problem-solving with the community." Dominique Debucquoy-Dodley \& Shimon Prokupecz, Grand Jury Decision Expected This Week in NYPD Chokehold Death Case, CNN.com (last updated Dec. 8, 2014), http://edition.cnn.com/2 014/12/02/justice/new-york-grand-jury-chokehold; see also Stephen J. Schulhofer et al., American Policing at a Crossroads: Unsustainable Policies and the Procedural Justice Alternative, 101 J. CRIM. L. \& CRIMINOLOGY 335, 340 (2011).

249. For general criticisms of problem-solving courts, see NAT'L ASS'N OF CRIMINAL DEF. LAWYERS, AMERICA's PROBLEM-SOlving COURTS: THE CRIMINAL CoSTS OF TREATMENT AND THE CASE FOR REFORM 10 (2009), https://www.nacdl.org/WorkArea/linkit.aspx?LinkIdentifier=id\&It 
the criminal system less, well, criminal can prove complicated, costly, and self-defeating. ${ }^{250}$

In the HTICs, it is not so clear what best procedural justice practices entail, as the divergence of judicial style described above suggests. While it is safe to say most defendants would not enjoy being humiliated by court personnel, some might prefer a limited efficient interaction over extended judicial dialogue that probes the details of their lives, even if sympathetic. And while defendants might find it dignified to tell their side of a traffic ticket story (a favorite example of procedural justice adherents), ${ }^{251}$ perhaps the same cannot be said of defendants telling their side of a commercial sex story. Moreover, reforms may have unintended effects. Centralization reflects an effort to improve communication among attorneys, court personal and service providers in order to facilitate defendant care. At the same time, centralization has also introduced an element of spectacle and shaming reminiscent of much older prostitution courts. ${ }^{252}$ A Brooklyn defense attorney explained:

It's a little bit of a circus. My clients come in; sometimes their pimps show up; and there are all these people

emID $=20217$; Richard C. Boldt, Rehabilitative Punishment and the Drug Treatment Court Movement, 76 WASH. U. L.Q. 1205, 1245-60 (1998); Morris B. Hoffman, A Neo-Retributionist Concurs with Professor Nolan, 40 AM. CRIM. L. Rev. 1567, 1567-70 (2003); Morris B. Hoffman, Therapeutic Jurisprudence, Neo-Rehabilitationism, and Judicial Collectivism: The Least Dangerous Branch Becomes Most Dangerous, 29 FORDHAM URB. L.J. 2063, 2084 (2002); Tamar M. Meekins, Risky Business: Criminal Specialty Courts and the Ethical Obligations of the Zealous Criminal Defender, 12 BERKELEY J. CRIM. L. 75, 107-08 (2007); Tamar M. Meekins, "Specialized Justice": The Over-Emergence of Specialty Courts and the Threat of a New Criminal Defense Paradigm, 40 SufFolK U. L. REv. 1, 12-13 (2006); Eric J. Miller, Drugs, Courts, and the New Penology, 20 STAN. L. \& POL'y Rev. 417, 445-46 (2009); Eric J. Miller, Embracing Addiction: Drug Courts and the False Promise of Judicial Interventionism, 65 OHIO ST. L.J. 1479, 1575-76 (2004); Mae C. Quinn, The Modern Problem-Solving Court Movement: Domination of Discourse and Untold Stories of Criminal Justice Reform, 31 WASH. U. J.L. \& POL'Y 57, 58 (2009); Mae C. Quinn, Whose Team Am I on Anyway? Musings of a Public Defender About Drug Treatment Court Practice, 26 N.Y.U. REv. L. \& Soc. Change 37, 54-63 (2001); Corey Shdaimah, Taking a Stand in a Not-So-Perfect World: What's a Critical Supporter of Problem-Solving Courts to Do?, 10 U. MD. L.J. RACE, RELIGION, Gender \& Class 89, 97-104 (2010).

250. And, in fact, they can obscure the coercive nature of criminal court in the process. See Malkin, supra note 176, at 368 ("The devolution of power into such a complex web means it becomes harder not only to trace how the final outcomes are determined, but also, protesting these changes becomes almost impossible from the perspective of the average citizen.").

251. See LiND \& TYLER, supra note 245 , at 82-83; TOM R. TYLER \& YUAN J. HuO, TRUST IN the LaW: EnCouraging Cooperation With the Police and the LaW (2002); Gold \& Bradley, supra note 247; Schulhofer et al., supra note 248, at 346-47.

252. Mae C. Quinn, Revisiting Anna Moscowitz Kross's Critique of New York City's Women's Court: The Continued Problem of Solving the "Problem" of Prostitution with Specialized Criminal Courts, 33 FORDHAM URB. L.J. 665, 677 (2006). 
observing. There are these detectives, and there are always program people. . . . Even the court officers will come up and watch. It's the prostitution part. It's the sex part. People are drawn to this topic, and I think that they like watching it for whatever value it provides for them-entertainment or whatever. And I feel like my clients just accept a certain amount of mockery and public shame because it just comes with the turf. ${ }^{253}$

Of course, court reform to produce a less punitive and more dignified experience for criminal defendants is a worthy endeavor, even if it does not always work. Nevertheless, reform from within comes with a significant potential downside: It can prevent alternatives like reform from without or simply phasing-out. Reformers often imagine their work contributing to a robust resolution to a problem or at least a step in the right direction, and consequently down-play the stickiness of pre-existing norms and the possibility that costs are endemic to the system. ${ }^{254}$ In this way, and as the next section explores, reformed comes at the expense of less.

\section{B. Sustaining Criminalization: From Public Order to Penal Welfare}

The HTICs have, to a significant extent, reduced convictions and jail sentences for prostitution defendants, although there is no data on how they have affected pretrial detention. ${ }^{255}$ In this sense, the HTICs are worlds away from the public-order model that punished low-level 2014).

253. Interview with Ryan Wall, Attorney, Legal Aid Soc'y, in New York, N.Y. (June 25,

254. For example, in the wake of a slew of racialized police shootings and racial policing practices, commentators have been quick to call for body cameras, de-biasing, and similar practices as the solution to the problem. But these seem to come at the cost of a more straightforward response to policing problems-fewer police and fewer arrests. See Police Reforms Proposed After Milwaukee Shooting, CNSNEws.COM (Dec. 23, 2014, 9:36 PM), http://cnsnews.com/news/article/police-reforms-proposed-after-milwaukee-shooting (noting a reform proposal for "spending $\$ 1$ million to equip every Milwaukee officer with a body camera and creating an 'early warning system' that would use citizen complaints and performance reviews to identify aggressive officers who may pose a threat to the public and get them counseling"); Wesley Lowery, WH Task Force: All Police Shootings Should Be Independently Reviewed, WASH. POST (Mar. 2, 2015), http://www.washingtonpost.com/news/postpolitics/wp/2015/03/02/wh-task-force-all-police-shootings-should-be-independently-reviewed (noting "the task force report contains a litany of recommendations" including body cameras, and the "eradicat[ion of] all forms of biased policing"). But see Conor Friedersdorf, Calling Someone Other Than the Cops, ATLANTIC (May 6, 2015), http://www.theatlantic.com/politics/archive/2015/0 5/calling-someone-other-than-the-cops/392378 (arguing that "[m]any kinds of urban disorder would be better addressed by people who aren't police officers").

255. See supra note 235 and accompanying text. 
offenders to reduce visible disorder and crime rates overal. ${ }^{256}$ Within current New York criminal justice parlance, it is no longer presumed that prostitution is the harbinger of more serious crime. Instead, it is the serious crime of trafficking that creates prostitution. If the late 1980s and early 1990s represent the zenith of broken windows theory, the last few years represent its nadir. ${ }^{257}$ For myriad reasons, legal reformers are increasingly skeptical of the benefits of "cleaning up the streets" by enforcement against minor offenders, including sellers of sex, and quite cognizant of its costs. ${ }^{258}$ So why have prostitution arrests in New York City continued on pace with other misdemeanor arrests?

Court reform is invariably preceded by reformers' efforts to define and publicize the relevant social problem. Trafficking discourse revived the notion of commercial sex as a high-level criminal problem meriting a strong and coordinated police response, not just a nuisance to be tolerated or trade to be regulated. ${ }^{259}$ Within this dynamic, "doing something" about sex trafficking does not translate simply into immigration reform, a

256. See supra Section I.A.

257. See, e.g., Charlie Gerstein \& J.J. Prescoth, Commentary, Process Costs and Police Discretion, 128 HARV. L. REV. F. 268, 268-70 (2015); Andrew Ingram, Breaking Laws to Fix Broken Windows: A Revisionist Take on Order Maintenance Policing, 19 BERKELEY J. CRIM. L. 113, 12931 (2014); see also Nancy A. Heitzeg, "Broken Windows," Broken Lives and the Ruse of "Public Order" Policing, TRUTHOUT (July 17, 2015, 12:00 AM), http://www.truth-out.org/opinion/item/319 36-broken-windows-broken-lives-and-the-ruse-of-public-order-policing; Heather Mac Donald, How Broken Windows Policing Puts Fewer Men in Prison, TIME (Dec. 17, 2014), http:/time.com/3 638183/eric-garner-nypd-broken-windows-policing.

258. In addition, even during the public-order era, moral condemnation of prostitution had been, for the most part, relegated to a puritanical minority. Tellingly, the conservative antipornography advocacy group "Morality in Media," which campaigned against the indecency of pornography on religious moral grounds, has now rebranded itself the "National Center on Exploitation." Hysen Sisco, We Changed Our Name!, Morality IN MEdia (Feb. 20, 2015), https://web.archive.org/web/20150322234649/http://pornharms.com/changed-name. Morality in Media President Patrick Trueman praised the "inspired" move:

Over the past few years, we have noticed that many in the public, including the press and potential supporters, disregard us automatically based on the name Morality in Media. ... We will continue to fight for morality and decency with all of the force we have, but ... the name National Center on Sexual Exploitation will allow us to reach a broader audience with our message. Already, we have seen incredible momentum under this new name.

Id.

259. See, e.g., Melissa Farley, Prostitution, Liberalism, and Slavery, Logos J., Fall 2013, http://logosjournal.com/2013/farley [hereinafter Farley, Liberalism]; Melissa Farley, Prostitution Is Sexual Violence, PSYCHIATRIC TIMES, Oct. 2004, http://www.psychiatrictimes.com/sexualoffenses/prostitution-sexual-violence [hereinafter Farley, Sexual Violence]. 
secure social safety net, or affordable housing, ${ }^{260}$ but rather calls for eradicating the global trade of women and forcefully prosecuting "real" criminals-traffickers. ${ }^{261}$ Yet anti-trafficking reform in New York City and elsewhere does not only direct penal authority against high-level offenders-traffickers and buyers. ${ }^{262}$ As it is presently unfolding in the United States, anti-trafficking activism also maintains penal control of low-level offenders, namely sellers of sex.

To be sure, many of today's prostitution abolitionists support decriminalization of sellers while amplifying enforcement against buyers and profiteers. ${ }^{263}$ Empiricists and theorists hotly debate whether harsh prosecution of (primarily male) purchasers and traffickers coupled with tolerance for (primarily female) sellers is better for women than general decriminalization or legalization, in terms of making them safer or creating avenues of exit. ${ }^{264}$ For us, that question is somewhat beside the

260. Sociologist Ronald Weitzer explains that the trafficking "paradigm depicts all types of sexual commerce as institutionalized subordination of women, regardless of the conditions under which it occurs. The perspective does not present domination and exploitation as variables but instead considers them core ontological features of sexual commerce." Ronald Weitzer, Sex Trafficking and the Sex Industry: The Need for Evidence-Based Theory and Legislation, $101 \mathrm{~J}$. CRIM. L. \& CRIMINOLOGY 1337, 1338 (2011) (footnote omitted).

261. Horrific descriptions of abuse of sex trafficking victims and a call for accountability of the perpetrators figure prominently into the discourse. See, e.g., MacKinnon, supra note 119, at 275; Farley, Liberalism, supra note 259; Farley, Sexual Violence, supra note 259; see also Weitzer, supra note 260, at 1344-46 (discussing the melodramatic portrayals of commercial sex).

262. This movement has gained traction in the United States and has led to several state and local demand-focused law enforcement campaigns. See, e.g., Jeff Kolkey, Area Law Enforcement Urges Department of Justice to Take on Backpage over Prostitution, ROCKFORD REG. STAR (Feb. 2, 2016, 5:17 PM), http://www.rrstar.com/article/20160202/NEWS/160209886; Jim Provance, More Penalties for 'Johns' Up for Vote Today, TOLEDo BlaDE (May 28, 2014), http://www. toledoblade.com/Politics/2014/05/28/More-penalties-for-johns-up-for-vote-today.html; Tabitha Woodruff, Go After Johns to Reduce Sex Trafficking, ColuMBUS DiSPATCH (Mar. 4, 2014, 9:1 1 AM), http://www.dispatch.com/content/stories/editorials/2014/03/04/1-go-after-johns-to-reducesex-trafficking.html. On the federal level, this is evidenced by the recent passage and signing into law of the Justice for Victims of Trafficking Act, which, among other things, redefines trafficking to include those who only patronize a victim of trafficking, without more, and provides specific grant assistance for "the establishment or enhancement of problem solving court programs for trafficking victims." Justice for Victims of Trafficking Act of 2015, Pub. L. No. 114-22, § 203, 129 Stat. 227, 231-32 (codified as amended at 42 U.S.C. 14044b (2012)).

263. See, e.g., Equality Now Advocates for 'Nordic Model' Against Trafficking and Gender Inequality, EQUALITY NOW (Dec. 4, 2012, 2:15 PM), http://www.equalitynow.org/press_ clip/equality_now_advocates_for_nordic_model_against_trafficking_and_gender_inequality_th e_nor. For a careful and contextual description of different Nordic models, see generally MAYlen Skilbrei \& Charlotta Holmström, Prostitution in the Nordic Region: Ambiguous SYMPATHIES (2013).

264. For arguments that this model (the Swedish model) is good for women, see Dianne Post, Prostitution Cannot Be Squared with Human Rights or the Equality of Women, CATO UNBOUND (Dec. 6, 2013), http://www.cato-unbound.org/2013/12/06/dianne-post/prostitution-cannot-be-squar 
point because in New York and elsewhere in the United States, amped up law enforcement against traffickers has not coincided with decriminalization of prostitution suspects. ${ }^{265}$ To the contrary, it appears that prostitution arrests have been absorbed into the anti-trafficking mission.

For example, the New York Lawyer's Manual on Human Trafficking describes "arresting the victim" as a tool of trafficking interdiction. ${ }^{266}$ The entry, written by a former prosecutor, acknowledges that "views vary" and cautions that arrest may be self-defeating because it can

ed-human-rights-or-equality-women; Steven Wagner, Prostitution Is Exploitation, CATO UNBOUND (Dec. 9, 2013), http://www.cato-unbound.org/2013/12/09/steven-wagner/prostitution-exploitation. For criticisms of decriminalization only for sellers of sex, see Janie A. Chuang, Rescuing Trafficking from Ideological Capture: Prostitution Reform and Anti-Trafficking Law and Policy, 158 U. PENN. L. REv. 1655, 1718-21 (2010) ("A closer examination of social science studies evaluating the effectiveness of the Swedish model casts doubt on whether its potential to combat prostitution, much less trafficking, deserves such enthusiasm."); Prabha Kotiswaran, Born unto Brothels-Toward a Legal Ethnography of Sex Work in an Indian Red Light Area, 33 LAW \& SOCIAL INQUIRY 579; 606, 623-24 (2008) (empirical study in Bombay "red light" district finding that criminal regulations transferred the sex trade to riskier transient sex worker on the outskirts of the city); Julie Sou et al., Structural Determinants of Inconsistent Condom Use with Clients Among Migrant Sex Workers: Findings of Longitudinal Research in an Urban Canadian Setting, 42 SEXUALLY TRANSMITTED DISEASES 312, 315 (2015) (arguing that decriminalized indoor workspaces remain needed to facilitate workplace safety and provide HIV and STI prevention); Aziza Ahmed \& J.M. Kirby, Preventing HIV: The Decriminalisation of Sex Work, 50.50 InCluSIVE DEMOCRACY (Aug. $11, \quad 2014$ ), https://www.opendemocracy.net/5050/aziza-ahmed-jm-kirby/preventing-hivdecriminalisation-of-sex-work (arguing for general decriminalization on the grounds of sexworker safety).

Even assuming harsh prosecution of purchasers and promoters is good for trafficked women, there remains the question of whether it is what they want. Maggie McNeill, for example, argues not just that empirically the Swedish model "has been demonstrated to increase both violence and stigma against sex workers," but also that the model makes "insulting and demeaning assumptions about women's agency." Maggie McNeill, Treating Sex Work as Work, CATo UnBOUND (Dec. 2, 2013), http://www.cato-unbound.org/2013/12/02/maggie-mcneill/treating-sex-work-work. In the HTIC context, even those committed to an anti-trafficking prosecution paradigm acknowledge that prosecuting "intimate partner pimps" may run counter to the trafficking victims' desires. According to Judge Serita, "I don't think anybody believes mandatory separation works. And if you ask any social worker or counselor, they would advise against [it]. . . Maybe it is one of those situations where somebody is romantically involved or very much identified with or attached to their exploiter." Interview with Toko Serita, supra note 55. Likewise, public defender Zoe Root described attending a meeting of HTIC stakeholders to debate a bill to increase sentences for traffickers and buyers and then discussing the bill with a client. In Root's view: "It's not necessarily what anyone who is charged with prostitution wants." Interview with Zoe Root, supra note 181.

265. See supra note 148 and accompanying text.

266. Lauren Hersh, Sex Trafficking Investigations and Prosecutions, in LAWYER's MANUAL. ON Human Trafficking 255, 260 (Jill Laurie Goodman \& Dorchen A. Lleidholdt eds., 2013). Chief Judge Lippman referenced this document as important to the creation of the HTIC initiative. See Lippman, supra note 9. 
"ultimately reduc[e] any chance of cooperation."267 Yet it proceeds to carefully elucidate the anti-trafficking logic behind arresting the victim. ${ }^{268}$ Prosecutors benefit from prosecuting the victim, according to the manual, because they can then "maintain[] reliable contact," given that a criminal defendant is "required to make periodic court appearances and, in the event that she disappears, prosecutors can seek a warrant for her arrest." ${ }^{269}$ In addition, an arrestee who "fears prosecution may offer useful information in exchange for a dismissal." 270 In addition, the entry endorses hyper-surveillance of commercial sex activity, involving sting operations, wiretapping, clandestine observations, and on-the-street stops and questioning of prostitution suspects, regardless of arrest. ${ }^{271}$ And, according to the Manual, prostitution-arrest-pattern information is particularly useful for trafficking interdiction. ${ }^{272}$

This connection between prosecuting traffickers and arresting prostitution suspects has influenced reform efforts in New York and elsewhere. Consider, for example, Rhode Island's recent experience with criminalizing prostitution. From 1980 to 2009, prostitution was legal in Rhode Island, although related acts like transporting, profiteering, and loitering for prostitution were illegal. ${ }^{273}$ The legislature had acted in response to a sex-workers'-rights group's constitutional challenge to the state's public indecency law. 274 Even after the legislative change, police continued to raid indoor sex establishments, until a 2003 court case (involving a massage parlor raid sophomorically named "Operation Rubdown") made it clear that the act of commercial sex, standing alone, could not be ground for criminal prosecution. ${ }^{275}$ This case coincided with a wave of public frustration over the growing number of Asian massage parlors in Providence and spurred several legislative attempts to

267. Hersh, supra note 266 , at 260-61.

268. Id. at Zó0.

269. $I d$.

270. Id.

271. Id. at $258-61,263,265-66$.

272. Id. at 260.

273. Max Ehrenfreund, When Rhode Island Accidentally Legalized Prostitution, Rape Decreased Sharply, WASH. POST: WONKBLOG (July 17, 2014), https:/www.washingtonpost.com/ news/wonk/wp/2014/07/17/when-rhode-island-accidentally-legalized-prostitution-rape-and-stisdecreased-sharply/.

274. See Ray Henry, RI Lawmakers Reach Deal to Ban Indoor Prostitution, NASHUA TELEGRAPH (Oct. 27, 2009), http:/www.nashuatelegraph.com/news/statenewengland/409898227/ri-lawmakers-reach-deal-to-ban-indoor.html; Amanda Milkovits, Legislators Drop Bid to Outlaw Brothels, ProvidenCE J., June 16, 2005, at A1.

275. See Lynn Arditi, How R.I. Opened the Door to Prostitution, Providence J. (Nov. 14, 2014, 2:43 PM), http://www.providencejournal.com/article/20141114/News/311149994; Karen Lee Ziner, Police Bust 3 Massage Parlors in Providence, ProvidenCE J., Feb. 20, 2003, at B1. 
recriminalize indoor prostitution on both law-and-order and antitrafficking grounds. ${ }^{276}$

These attempts at recriminalization all stalled because of concerns over the human costs of arresting the women engaged in commercial sex. $^{277}$ That is, until 2009 when democratic house member Joanne Giannini joined with Rhode Island University women's studies professor and activist Donna Hughes and set out to reframe anti-prostitution legislation as anti-trafficking, period. ${ }^{278}$ Giannini introduced a reformulated prostitution-criminalization bill, which added penalties for maintaining a brothel and purchasing sex and provided an affirmative defense to trafficked women, together with a tough-on-trafficking bill that increased sentences for traffickers. ${ }^{279}$ This renewed anti-prostitution effort, deeply entwined with anti-trafficking provisions, drew the attention of the Rhode Island anti-trafficking coalition, and although the coalition did not take an official position on the prostitutioncriminalization portion, it held public rallies on the eve of the vote to express support for the entire legislative package. ${ }^{280}$

276. In 2005 , a bill made its way through the Rhode Island legislature to make the sale of sex a misdemeanor carrying a six-month penalty with support from the Providence mayor, who touted familiar broken windows rhetoric. R.I. Massage Workers Sore over Prostitution Crackdown, Fox NEwS (July 18, 2005), http://www.foxnews.com/story/2005/07/18/ri-massageworkers-sore-over-prostitution-crackdown.html; Amanda Milkovits \& Tracy Breton, Bill Aims to Crack Down on Massage Parlors, PRovidence J., June 28, 2005, at B1. The sponsors of the bill ultimately withdrew it because of pressure from civil rights groups concerned with arresting women. See infra note 277 and accompanying text. Meanwhile, the police continued to raid massage parlors and arrest women prostitution suspects, but on immigration charges. Amanda Milkovits, Brothels Survive on Weak R.I. Law, ProvidencE J., Aug. 19, 2006, at A3. After the resounding defeat of the 2005 effort, the Providence mayor turned to "organizations that combat sexual abuse and human-trafficking to write effective legislation for the coming General Assembly session." Id. This caught the attention of democratic house member Joanne Giannini, who had previously sponsored an anti-trafficking bill. $I d$. Over the next several years, she, joined by law enforcement, religious groups, and the Providence mayor, sponsored a series of failed bills seeking to criminalize prostitution. See Lynn Arditi, Tougher Sex Laws Gain Backing, PROVIDENCE J., June 12, 2009, at B1. However, civil libertarian opponents continued to successfully push back, arguing that the law would punish and further harm women. See, e.g., Family Life Ctr., Rethinking ARrest: Street Prostitution and Public Policy in Rhode ISLAND 2009), http://www.ceffect.com/wp-content/uploads/2009/08/Rethinking-Arrest-StreetProstitution-and-Public-Policy1.pdf.

277. See Milkovits, supra note 274 (stating that the 2005 legislation was killed by "arguments from the ACLU and local activist group Direct Action for Rights and Equality that the legislation unfairly singled out women").

278. See Sarah Schweitzer, Many Seek Ban as Prostitution Thrives in R.I., Bos. GLoBE (Aug. 13, 2009), http://archive.boston.com/news/local/rhode_island/articles/2009/08/13/in_rhode_island_ battle_over_legal_prostitution_rages_on/. Hughes and her students had undertaken a project to document both the prevalence of brothels in Providence and expose "what the johns say about women." Id.

279. See Cynthia Needham, Bill Targets Loophole in Prostitution Law, Providence J., Apr. 9,2009 , at B1.

280. Lynn Arditi, R.I. in 'Eye of the Storm' in Sex Trafficking, Prostitution, LYNNARDITI.COM (Apr. 19, 2009) (reporting that "[t]he coalition grew out of a November 2006 
Progressives in the Senate objected to criminalizing the women and queried why it was necessary, given the provisions intensifying enforcement against purveyors, profiteers, and buyers. ${ }^{281}$ In response, the feminist activists in favor of recriminalization argued that the bill illegalizing prostitution generally gave the police tools to combat sex trafficking, without providing many details on how. ${ }^{282}$ Police and prosecutors, however, were more forthcoming. They explained that criminalizing the sale of sex would make it easier to obtain search warrants to raid brothels, pursue evictions, and induce cooperation against traffickers. ${ }^{283}$ Criminalizing victims was cast as a necessary means to a larger social end of eradicating trafficking, precisely by facilitating law enforcement. ${ }^{284}$ Concerned members of the Senate, in response, called for extensive police training on how to identify and respectfully treat trafficking victims. ${ }^{285}$ However, police pushed back against the training, arguing that it would be too expensive and cumbersome. ${ }^{286}$ In the end, despite objections from the ACLU, NOW, anti-domestic violence groups, and sex-workers'-rights advocates, ${ }^{287}$ the legislature made selling sex a crime carrying a six month sentence, with an affirmative defense of trafficking, but without any provision for police training. ${ }^{288}$

In New York, similar dynamics are at play. Consider the NYPD's crackdown on Brooklyn massage parlors in December 2014. ${ }^{289}$ The raids

gathering of more than 100 people at a forum in Providence ... sponsored by Mayor David $\mathrm{N}$. Cicilline and the National Council of Jewish Women").

281. See Lynn Arditi, Closing a Loophole, ProvidEnCE J., Oct. 28, 2009, at A1.

282. Donna Hughes stated of the Bill, "[w]e owe our neighbors a law that will prevent their women and girls from being abused in this state." Henry, supra note 274; see also Arditi, supra note 281 (quoting Giannini as stating that the bill "mean[s] police will no longer be powerless").

283. See Lynn Arditi, supra note 280 (quoting an ICE agent as stating that "we get [trafficking convictions] by potentially charging the victim with prostitution"); Henry, supra note 274 (discussing warrants); Ray Henry, Advocates Urge Defeat of RI Indoor-Prostitution Ban, S. COAST TODAY (June 10, 2009, 4:43 PM), http://www.southcoasttoday.com/article/20090610/Ne ws/90610015 ("To prosecute human traffickers, investigators sometimes need to arrest low-level prostitutes and pressure them to testify against higher-ups, State Police Col. Brendan Doherty said."); Milkovits, supra note 274 (noting that police cited the need to have prostitution arrests (not just unlicensed massage arrests) associated with the massage parlors in order to allow landlords to evict them).

284. Henry, supra note 283.

285. Arditi, supra note 281.

286. See Lynn Arditi, Anti-Prostitution Bills Await Votes, Providence J., June 24, 2009, at B3.

287. See Henry, supra note 283; Steve Peoples, Prostitutes Speak out Against Bill to Close Loophole, ProvidENCE J., Oct. 26, 2009, at A1.

288. See Arditi, supra note 280.

289. Rachel Silberstein, 15 Women Arrested, Nine Massage Parlors Shut down in Prostitution Sting, BENSONHURST BEAN (Dec. 4, 2014), http://www.bensonhurstbean.com/2014/ 
resulted in the arrests of fifteen Asian women. ${ }^{290}$ Prosecutors charged ten of the women with providing unlicensed massages, nine with prostitution, and two with promoting prostitution. ${ }^{291}$ Not one of the arrestees was charged with or prosecuted for trafficking. ${ }^{292}$ Despite this, the raids were widely praised. $^{293}$ As William Bratton, who was once again commissioner of the NYPD, put it:

As a result of these arrests, we hope to address the issue of prostitution in these communities and the possibility that these individuals may be victims of human trafficking. The New York City Police Department, in partnership with the Kings County District Attorney's Office, remains committed to improving the quality of life for residents and stopping those who profit from the exploitation of others. ${ }^{294}$

Bratton's praise thus incorporated both public-order/quality-of-life and anti-trafficking sentiments by promising to go after serious criminals (traffickers) while simultaneously arresting petty criminals now understood as victims. After the Brooklyn raids, prosecutors promised. that arrestees would be screened for "signs of human trafficking" and possible program placement, prompting the Mayor's Director of Criminal Justice, Elizabeth Glazer, to opine that the "approach to addressing human trafficking" embodied by the raids "demonstrates how an array of tools, from law enforcement and beyond, can be effective in not just making a case but solving a problem."295 Glazer had thus reconceived arresting the victim not as a human cost of trafficking interdiction but as a net benefit. ${ }^{296}$

12/15-women-arrested-nine-massage-parlors-shut-down-in-prostitution-sting/\#.VcS_M_mqqko.

290. Id.

291. $I d$.

292. $I d$.

293. $I d$.

294. Press Release, Brooklyn Dist. Attorney's Office, 15 Women Arrested in Prostitution/Human Trafficking Investigation of Brooklyn Massage Parlors (Dec. 4, 2014), http://brooklynda.org/wpcontent/uploads/2015/03/15-women-arrested-in-prostitution.pdf (emphasis added).

295. Silberstein, supra note 289.

296. To be sure, many still hold public-order views. New York State Senator Vincent Gentile, for example, explained, "These establishments are an embarrassment to and a scourge on our community. . . . Indeed, businesses like these have no place in our strong, safe and family oriented community. This is a big victory." Press Release, Brooklyn Dist. Attorney's Office, supra note 294. But the HTICs enable proponents to view public order policing of prostitution offenses with no (or little) downsides precisely because arrest is beneficial or at least minimally harmful. 
This pattern played out again during the 2014 Super Bowl, which took place in the New York City metropolitan area. ${ }^{297}$ Anti-trafficking advocates astutely used this (and other) highly publicized sporting events to raise social awareness about the widespread problem of human trafficking. ${ }^{298}$ The police, not surprisingly, responded with a crackdown on prostitution, resulting in an increase in prostitution arrests and, by extension, cases coming into the HTICs. ${ }^{299}$ As with the massage parlor arrests, some law enforcement officials simply repeated that these arrests were necessary to keep communities safe during a time of increased visits and parties. ${ }^{300}$ Again, however, the trafficking paradigm played a significant role in re-envisioning the arrests of the victims as beneficial. In addition to headlines proclaiming that arrested juveniles were "rescued,"301 HTIC practice, portrayed as nonpunitive and even benevolent, served to sanitize the arrests of presumptively trafficked adults. ${ }^{302}$

297. See Mary Pilon, Jump in Prostitution Arrests in Super Bowl Week, N.Y. Times (Jan. 29, 2014), http:/www.nytimes.com/2014/01/30/sports/football/jump-in-prostitution-arrests-in-super-b owl-week.html.

298. See id. ("In recent years, the Super Bowl has become a rallying point for antiprostitution and anti-sex trafficking groups."). See generally DOMINIQUE ROE-SEPOWITZ ET AL., ariz. State Univ. Sch. of Soc. WORK, Exploring Sex Trafficking and Prostitution Demand DURING THE SUPER BOWL 6(2014), https://www.mccaininstitute.org/applications/Exploring_Sex_Tr afficking_and_Prostitution_Demand_during_the_Super_Bowl_pdf (summarizing the results of a study aimed "to provide research-based information to future Super Bowl or other large event stakeholders about methods of research that can help to steer efforts towards sex trafficking prevention, detection and intervention").

299. See Kate Mogulescu, The Super Bowl and Sex Trafficking, N.Y. Times (Jan. 31, 2014), http://www.nytimes.com/2014/02/01/opinion/the-super-bowl-of-sex-trafficking.html.

300. See Jonathan Dienst, High-End Escorts Arrested in Super Bowl Prostitution, Cocaine Crackdown, NBC N.Y. (Jan 30, 2014, 12:12 AM), http://www.nbcnewyork.com/news/local/Sex-Tr afficking-Super-Bowl-Arrests-Brooklyn-Marriot-Sources-242695841.html (quoting N.Y. Attorney General Eric Schneiderman as stating, "Drug trafficking and prostitution are a scourge on communities across our state"'); Pilon, supra note 297 (quoting New York City Vice enforcement coordinator as stating that the arrests were due to police being "cautious and fearful that people are going to come with a mind-set that [prostitution] is acceptable").

301. See, e.g., Marina Lopes, 45 Arrested, 16 Juveniles Rescued in Super Bowl Prostitution Bust, REUTERS (Feb. 4, 2014), http://www.reuters.com/article/2014/02/04/us-nfl-superbowlprostitution-idUSBREA131BB20140204.

302. In response to Ms. Mogulescu's New York Times op-ed critiquing the increases in arrests, New York Attorney General Eric Schneiderman wrote a letter to the editor stating, "When my office took down a major drug and prostitution ring last week, our response reflected a major shift in American law enforcement, which has begun to treat prostitutes as crime victims, not criminals. ... [W] ] worked ... to ensure that victims received counseling and support." Eric Schneiderman, Letter to the Editor, The Victims of Human Trafficking, N.Y. TiMES (Feb. 5, 2014), http://www.nytimes.com/2014/02/06/opinion/the-victims-of-human-trafficking.html. More to the point, Michael Corriero, director of the New York Center for Juvenile Justice, responded by emphasizing that "last year, the New York court system created special human trafficking sections 
Consequently, in the stand-off between law and order and tolerance, between benefits and drawbacks of arrest, the fact that the HTICs involve potentially non-criminal dispositions coupled with benefits allows them to serve as a pivotal tiebreaker in favor of arrest. One prosecutor made such a connection: "In order to clean up the massage parlors, you end up having to arrest the people working in [them]... The way you deal with that is [you don't] saddle that person with a criminal record." 303 Some, like Glazer, suggest that arrests can advance social problem-solving and help victims. ${ }^{304}$ In a striking example, a recent New York continuinglegal-education program on underage victims of sex trafficking touted that participating attorneys would learn "how 'getting arrested' can turn from a prostitute's worst nightmare into a blessing in disguise." 305

Whether any prostitution defendant would agree that the HTICs are a blessing is beyond the scope of our research. Defense attorneys report that many clients appreciate the HTICs' services, although clients would prefer such services on a voluntary basis and certainly not as a consequence of an arrest they experience as harmful and degrading. ${ }^{306}$ But beyond the views of defendants themselves, there are several reasons to be suspicious of welfare administration through criminal law-what we call penal welfare.

At the outset, we should note that many public defenders, social workers, and sex-worker advocates asserted that they already possess the means to connect prostitution defendants to the services that currently exist, without the intervention of the HTICs. Using the criminal system to provide those services is thus neither a necessary nor a particularly efficient way to reach this population, given the economic costs of

that link prostituted people to specialized services with the aim of dismissing their cases." Michael Corriero, Letter to the Editor, The Victims of Human Trafficking, N.Y. TIMES (Feb. 3, 2014), http:/www.nytimes.com/2014/02/06/opinion/the-victims-of-human-trafficking.html; see also Pilon, supra note 297 ("In New York, prostitution can result in jail time of up to 90 days. But most of the women arraigned this week will enter various social service programs with ties to groups like housing and domestic violence prevention ....").

303. Telephone Interview with Anonymous Brooklyn Assistant Dist. Attorney, supra note 190.

304. See supra note 289 and accompanying text.

305. Flyer, N. Y. Chapter of the Nat'1 Ass'n of Women Judges; NYCLA's Judicial Section, Law Related Educ. Comm. \& Justice Ctr. (Apr. 23, 2015) (on file with authors); see also Brynn N.H. Jacobson, Comment, Addressing the Tension Between the Dual Identities of the American Prostitute: Criminal and Victim; How Problem-Solving Courts Can Help, 37 SEATTLE U. L. REv. 1023, 1024 (2014) (arguing for "continued criminalization for prostitution in the United States" when coupled with a "problem-solving court, similar to a drug court, which would provide a multidisciplinary approach to helping those trapped in prostitution").

306. Indeed, many of our interviewees, not just the defense attorneys, lamented that arrest was traumatic for the defendants. 
policing, prosecution, defending, and court administration and the social and human costs of arrests, court appearances, and incarceration. ${ }^{307}$

At the same time, over the past several decades states have become increasingly reluctant to address social problems and marginalized populations through means other than the criminal justice system. ${ }^{308}$ Within the dominant neoliberal political philosophy, governmentprovided welfare runs counter to both the efficient operation of the market and a moral script in which people rise or fall based on individual effort and merit. ${ }^{309}$ From within this discourse, criminal law intervention is one of the few permissible forms of state regulation because, unlike other forms of regulation, it polices only "true" transgressors (described by some in the law-and-economics field as those who break "market rules"). ${ }^{310}$ Indeed, sociologists have asserted that the criminal system has become the leading governance structure in the United States. ${ }^{311}$ Penal welfare thus becomes an add-on to a massive criminal system that has been legitimized precisely because it reflects individualist ethics of responsibility instead of principles of distributive justice. The danger, then, is that the more states and localities invest in penal welfare, the less that welfare, services, and aid bound not to arrest and prosecution-but redistribution — can gain legitimacy and secure funding. ${ }^{312}$

There are also practical reasons why penal welfare can easily eclipse service programs not directly tied to criminal court. Law-reform projects are resource heavy. As noted above, problem-solving courts are products of significant investments in publicity, personnel, training, and the like. Once such investments are made, it can become difficult for the state and individuals to divest and put their monetary, political, and expert capital

307. See FAMILY LIFE CTR., supra note 276 (discussing costs of criminalization model); Mogulescu, supra note 299 (arguing that the increase in policing and subsequent arrest strain the criminal justice system and harm the arrestees who face jail, deportation, and lifelong criminal records).

308. See Jeremy Kaplan-Lyman, Note, A Punitive Bind: Policing, Poverty, and Neoliberalism in New York City, 15 YALE HUM. RTs. \& Dev. L.J. 177, 179 (2012).

309. DAVID Harvey, A Brief History of NeOliberalism 19 (2005) (arguing that neoliberalization benefits the economic elites).

310. See, e.g., Bernard E. Harcourt, The Illusion of FreE Markets: Punishment and THE MYTH OF NATURAL ORDER 202-03 (2011) (asserting that the American penal state has "been facilitated by . . . the rationality of neoliberal penality: by, on the one hand, the assumption of government legitimacy and competence in the penal arena and, on the other hand, the presumption that the government should not play a role elsewhere"); Richard A. Posner, An Economic Theory of the Criminal Law, 85 COLUM. L. REv. 1193, 1195 (1985).

311. See, e.g., Harcourt, supra note 310; Jonathan Simon, Governing Through Crime: How the War on CRIME Transformed american Democracy and Created a Culture of Fear (2006); LoÏ Wacquant, Punishing the Poor: The Neoliberal Government of Social INSECURITY 297 (2009).

312. See Gruber, supra note 58, at 764; Malkin, supra note 176 , at $366-68$. 
elsewhere. The risk is that law- and policy-makers, facing scarcity of resources, then dismiss proposals that address problems outside of the criminal system as wasteful or duplicative, or worse, reject them because of "turf" concerns. The reformed criminal court then becomes its own cottage industry with permanent players, internal reports, cultural norms, and specialized knowledge production. ${ }^{313}$ The service providers become entangled in this penal welfare system and, in turn, have difficulty operating outside of it. Funding and other resources become increasingly tied exclusively to the criminal program, such that the penal welfare system becomes all-encompassing, crowding out noncriminal avenues of change. ${ }^{314}$

In sum, we urge reformers to be cognizant of the ways in which the HTIC program sustains the view that commercial sex is primarily a criminal problem that merits, at a minimum, a penal welfare, if not a lawand-order solution. As we have seen, supporters of the HTICs justify arrest as a weapon in the larger war against human trafficking and simultaneously as a de minimis, if not benign, intervention in arrestees: lives. But there are many downsides to designating the criminal system as the primary site for social services for people engaged in prostitution, including reinforcing an anti-distributive neoliberal ethic, administering benefits in a costly and unnecessarily painful manner, and operatively blocking less punitive modes of remediation. Indeed, in the HTIC system, the two options for prostitution defendants are to utilize criminal court services to leave the life or continue with underground, unregulated, criminal prostitution. The possibility of accessing state regulation to advance an improved commercial sex trade is simply off the table. And given that the HTIC system does not provide sufficient conditions for most women to leave the life, a fact stakeholders nearly universally admit, the impossibility of this regulatory third way is significant.

\section{Sex Exceptionalism and Limitations of the HTIC Model for Broader Criminal Reform}

As much as we have endeavored to show that HTIC reform may actually sustain or even amplify the criminalization of prostitution even as it promotes decarceration, we recognize that decarceration and dismissal, when compared to incarceration and conviction, are more

313. See, e.g., Frazer, supra note 247 , at 4, 19-20, $22-24$.

314. Recently, the New York City court system received an allocation of $\$ 750,000$ from the City Council "to provide services to survivors of human trafficking in specialty courts." Press Release, Council of the City of New York, Speaker Mark-Viverto, Mayor De Blasio and City Council Announce FY 2016 Budget Agreement to Add More NYPD Officers to the Beat, Establish a Citywide Bail Fund and Create Year Round Youth Employment (June 22, 2015), http://council.nyc.gov/html/pr/062215budget.shtml. 
desirable options for prostitution defendants. The HTIC system seeks to treat such defendants leniently and with dignity specifically because of their difficult life circumstances. For left-progressive penal theorists who recall the "rotten social background" defense's utter failure to launch, the HTICs may provide a spark of hope. ${ }^{315}$ One could characterize many crimes as products of defendants' dire circumstances and direct or indirect coercion. For sure, many defendants would not choose to be gang members, street-level drug dealers or users, petty thieves, burglars, vagrants, etc., without some coercive circumstances that limit their alternatives. Many defendants, male and female, suffer horrific violence on a regular basis. However, the discourse and philosophy of the HTICs contain internal limitations, namely, they self-consciously apply to only prostitution defendants for reasons grounded in a particular set of assumptions about women, sex, and women's relationship to sex..$^{316}$

This is the case, we should add, even as many HTIC reformers do express desires to create alternatives to incarceration in the larger criminal justice system. CCI stakeholders, for example, have developed pilot projects to create less punitive experiences for victim-defendants of domestic violence, not simply for victim-defendants of coerced commercial sex. ${ }^{317}$ But despite these commitments, what exploded throughout the state of New York are diversionary programs for only prostitution defendants and for only the crime of prostitution-not for any victim of violence who commits a crime or even for battered women who commit non-prostitution crimes. ${ }^{318}$ As CCI Director Bryan observed: "There's a carve-out right, there's obviously some reason that

315. See, e.g., Andrew E. Taslitz, The Rule of Criminal Law: Why Courts and Legislatures Ignore Richard Delgado's Rotten Social Background, 2 ALA. CIV. RTS. \& Civ. LiBERTIES L. REV. 79,80 (2011). The rotten social background issue was first introduced by Judge Bazelon, who opined that there might be "a significant causal relationship between violent criminal behavior and 'rotten social background' . ... [requiring] us to consider, for example, whether income redistribution and social reconstruction are indispensable first steps toward solving the problem of violent crime." United States v. Alexander, 471 F.2d 923, 965 (D.C. Cir. 1973) (Bazelon, J., dissenting) (footnote omitted).

316. Although Judge Camacho focused particularly on victims of domestic violence, at this time, the benefits of the HTIC are available only to prostitution defendants and not to other classes of defendants who experience domestic violence.

317. Miriam Goodman, for example, suggests that the current focus on prostitution defendants "is an opportunity to expand the conversation and on the ground programming for survivors of violence who are involved in the criminal justice system. For example, one particularly underserved population is men of color who witness violence in their neighborhoods and communities and then commit crimes." Interview with Miriam Goodman, supra note 177.

318. See supra Subsection II.B.4 (discussing the court system's treatment of prostitution defendants who have other charges). 
people are choosing the prostitution cases over other kinds of cases over the last five, six years.

As we traced in Part $\mathrm{I}$, this "carve-out" coincides with the extraordinary advocacy of prostitution-abolitionist feminists, such as Judge Kluger, who have inscribed the HTICs' official position that selling sex, in particular, is not an act of agency. ${ }^{320} \mathrm{We}$ encountered this perspective repeatedly in the HTICs. Numerous and important stakeholders adopt what we call a "sex exceptionalist" position: distinguishing prostitution defendants from other classes of marginalized and disadvantaged defendants because engaging in commercial sex causes specific and particularly pernicious harms. ${ }^{321}$

As with most aspects of the HTICs, this sex exceptionalist approach has positives and negatives. Sex, in fact, has long been and remains a gendered phenomenon. Sociological studies demonstrate that young women have a different relationship to sex than young men and are influenced by different expectations and emotions. ${ }^{322}$ Quite simply, the decision to have sex, whether or not for pay, remains more fraught for women than men. ${ }^{323}$ And sex for pay is stigmatizing regardless of gender. ${ }^{324}$ Consequently, it is reasonable to hold that as long as prostitution remains devastating to women's social status, the criminal system should regard a woman's (presumptively coerced) engagement in commercial sex as particularly victimizing. In this sense, a woman compelled to sell sex by a promoter, intimate partner, or life's

319. Interview with Courtney Bryan, supra note 88.

320. See Kluger, supra note 53 ("Anyone who thinks that prostitution is a victimless crime or a chosen 'profession' needs a history lesson. ... [T] he vast majority of children and adults charged with prostitution offenses are commercially exploited or at risk of exploitation.").

321. Cf. Katherine M. Franke, Theorizing Yes: An Essay on Feminism, Law, and Desire, 101 COLUM. L. REV. 181, 208 (2001) ("Women's sexual pleasure is not currently recognized in law as a major life activity."); Margo Kaplan, Sex-Positive Law, 89 N.Y.U. L. REv. 89, 91 (2014) (noting "the law's unspoken assumption that sexual pleasure has negligible or negative value"). The "sex exceptionalist" view is that sex is a particularly risky, potentially highly damaging act to women, made even more risky or damaging when done for commercial reasons, justifying the presumption that those who engage in commercial sex are not doing so out of free will.

322. See, e.g., KathleEn A. Bogle, Hooking Up: Sex, Dating, and Relationships on CAMPUS 97 (2008); Rachel Allison \& Barbara J. Risman, A Double Standard for "Hooking Up": How Far Have We Come Toward Gender Equality?, 42 SoC. SCI. ReS. 1191, 1191-1193 (2013).

323. See sources cited supra note 322; see also Andrew E. Taslitz, Forgetting Freud: The Courts' Fear of the Subconscious in Date Rape (and Other) Cases, 16 B.U. PUB. INT. L.J. 145, 155 (2007) ("[E]ven the most well-meaning, 'feminist' jurors may find that they have a reasonable doubt about the ... rape case ... if the tale told fits cultural stories about 'sluttish women.").

324. Cf. Ronald Weitzer, Male Prostitution, in THE Routledge HandBook of Deviant Behavior 378, 379 (Clifton D. Bryant ed., 2011) (noting that male sex workers are "less stigmatized within the gay community but more stigmatized in the wider society because of the coupling of homosexuality and prostitution" (citations omitted)). 
circumstances arguably suffers greater harm than, say, a drug addict compelled by his dealer or other circumstances to sell drugs or commit petty theft.

Feminists also justify sex exceptionalism and prostitution abolition by asserting that the very existence of commercial sex, pornography, and the like is bad for women because they reinforce the idea that women are rightfully objects of male sexual domination. ${ }^{325}$ From this perspective, commercial sex is a form of gender oppression. As Dorchen Leidholdt, Director of the Center for Battered Women's Legal Services at New York City's Sanctuary for Families, stated in a city council hearing: "Given the fact that the vast majority of those being arrested for prostitution are women, and the vast majority of patronizers are male, this disparity raises the specter of systematic gender discrimination." ${ }^{326}$ Judge Serita likewise articulated a version of this position:

I think one of the reasons why people are looking at prostitution for diversionary programs is because it is such a pronounced form of gender violence and also because it really does call into question so many of our assumptions about the role of women, right? How we treat women, what we do with women, the whole act of, you know, the commercial sex trade, and what that means. ${ }^{327}$

Sexual objectification and abuse are surely tools of male domination, and sex obviously implicates complex gender relations. ${ }^{328}$ Nevertheless, the effectiveness of sex as a tool of patriarchy and male hierarchy relates directly to its ability to negatively affect women, both internally and externally. The more irrelevant (or beneficial) sex is to one's self-worth, psychological health, and social standing, the less its dominating potential. ${ }^{329}$ As such, feminist reformers should take care that they do not reinforce the very inequality they protest. The HTICs seek to treat prostitution defendants with dignity as victims of male coercion. But the

325. See supra text accompanying notes 96-98 (discussing this view of pomography).

326. Oversight: Combating Sex Trafficking in NYC: Examining Law Enforcement EffortsPrevention and Prosecution: Hearing Before the Committees on Public Safety and Women's Issues, 2010-2013 Sess. 154-55 (N.Y.C. Council 2011) (statement of Dorchen Liedholdt, Dir., Ctr. for Battered Women's Legal Servs.), http://legistar.council.nyc.gov/Legislation.aspx (search "T2011-3774" for the year 2011; then follow the "T2011-3774" hyperlink in the results; then follow the "Hearing Transcript" hyperlink in the Attachments row on the resulting webpage).

327. Interview with Toko Serita, supra note 55.

328. See, e.g., Abrams, supra note 103, at 354.

329. Cf. Martha Chamallas, Deepening the Legal Understanding of Bias: On Devaluation and Biased Prototypes, 74 S. CAL. L. REv. 747, 786 (2001); Duncan Kennedy, Sexual Abuse, Sexy Dressing and the Eroticization of Domination, 26 NEw ENG. L. REv. 1309, 1322 (1992) (noting the regulatory effect of fear of sexual victimization). 
views of commercial sex the HTICs instantiate (slavery, trauma, exploitation) relegate prostitution to the realm of utmost deviance and shame and prostitution defendants to people with no agency at all. ${ }^{330}$ Telling prostitution defendants that they are victims of modern day slavery, as the name "human trafficking intervention courts" necessarily implies, seems unlikely to reduce feelings of shame and stigmatization. Some HTIC advocates in fact characterize prostitution defendants as perpetual children to justify their lenient treatment while simultaneously describing prostitution as a pressing problem akin to child sexual abuse. ${ }^{331}$

But here, as in all areas of the HTICs, practice on the ground is complex. Prosecutors clearly remain all too willing to distinguish between the HTIC defendants who are coerced childlike victims and those who are volitional criminal actors. ${ }^{332}$ Certain judges question the radical prostitution-abolitionist position. Judge Serita for example ventures that some people may sell sex volitionally, albeit very likely not the defendants she sees in her courtroom. ${ }^{333}$ Many social workers argue for harm reduction and explain that they respect their clients' choice to engage in commercial sex work. As a social worker in a public defender office elaborated: "We respect the fact that they're earning money and this is the way they are choosing to do so. Some people are making more money doing sex work than they would in other jobs." 334 Recognizing that defendants, especially those with extensive rap sheets, will therefore

330. See supra note 94 and accompanying text.

331. Activists start with the argument that most adult prostitution defendants were abused or exploited as children. See, e.g., Kluger, supra note 53 ("[P]rostitution defendants typically entered this 'profession' between the ages of 12 and 14 . Their average age of mortality is 34 years old. Between 65 and 96 percent are sexually assaulted as children ...."). Such facts prefigure an altogether different paradigm for adults. For example, new abolitionist Norma Ramos argued to the New York City Council: "Please do not take the easy road out and just focus on children, it is important and all the advocates before me addressed the importance of including women. ... [W]e must not turn our backs on those ex-children, is who I call them, who will more than likely still remain in prostitution ...." Resolution Calling on Village Voice Media to Stop Accepting Adult Services Advertisements on Its Online Classified Site, Backpage.com, Because It Serves as a Platform to Traffic Minors and Adult Victims for Sex: Hearing Before the Committee on Women's Issues, 2010-2013 Sess. 165 (N.Y.C. Council 2012) (statement of Norma Ramos, Exec. Dir., Coalition Against Trafficking in Women) (emphasis added), http://legistar. council.nyc.gov/Legislation.aspx (search "1226" for the year 2012; then follow the "Res 12262012" hyperlink in the results; then follow the "Hearing Transcript 4/25/12" hyperlink in the Attachments row on the resulting webpage).

332. See supra Subsection II.B.4.

333. Interview with Toko Serita, supra note 55. She suggests that most instances of street level prostitution she sees involve "very very poor defendants," the "people who are the most powerless and disadvantaged" and not "self-empowered 'sex workers' deciding what to do with one's body and the law coming into conflict with that." Id.

334. Interview with Anonymous N.Y.C. Social Worker, in New York, N.Y. (June 26, 2014). 
"go back out there because there they are working," this social worker tells the defendants she counsels: "Go with your regular clients, don't take the chance of meeting an undercover cop and getting arrested again, especially during your case ... it's more important to keep yourself safe." 335

But the fact remains that this is not the official rhetoric of the HTICsindeed, the language of harm reduction rather than abolition subverts official rhetoric. ${ }^{336}$ The official position of the HTICs, one adopted by many, although not all, of its stakeholders, is that commercial sex is a specific gender-based harm that necessarily grows out of coercion rather than agency - even agency that is constrained, as is so often the case, by a range of material and emotional needs. ${ }^{337}$ Judge Kluger, for example, asserts that the HTICs offer "a wide range of life-changing legal and social services that help [prostitution defendants] escape the violence and degradation of prostitution and trafficking" and that "[j]udges, prosecutors and defense lawyers work together to link victims with the services they need to transform and save their lives." 338 This position eschews the notion that commercial sex can sometimes provide women a viable avenue of economic existence and that interventions might simply strive to make this work safer and more tolerable. To that end, this position holds little tolerance for the sex-workers' rights agenda, which favors normalizing and regulating sex work to reduce harm rather than criminalizing it. ${ }^{339}$ To the contrary, official HTIC rhetoric seeks to destigmatize prostitution defendants, not by claiming that commercial sex is a legitimate form of work deserving of state protection, but by asserting that prostitution defendants are victims of men (traffickers and buyers) - men who are engaged in very shameful sexual activity. ${ }^{340}$

This presumption that prostitution defendants are victims - and in particular sex assault victims (akin to child sex assault victims)-has significant downsides, even as it has produced some tangible benefits for prostitution defendants by increasing noncriminal dispositions and offering services. Prosecutors and judges have used precisely this presumption to justify arrests and incarceration as a means of protecting victims and gathering information about traffickers. They have also limited lenient dispositions to prostitution offenses. Because the mercy

335. Id.

336. See Farley, Liberalism, supra note 259 (arguing, from an abolitionist perspective, that harm reduction without a commitment to helping people leave prostitution entirely "contribute[s] to a denial of the harms of prostitution").

337. See, e.g., Lippman, supra note 9.

338. Kluger, supra note 53 (emphasis added).

339. See, e.g., Letter to Amnesty Int'l, supra note 7 (stating that "[h]arm reduction is not enough,... governments and civil society must invest in harm elimination" through criminalization of prostitution).

340. See supra note 264 and accompanying text. 
of the HTIC is tethered to a depiction of prostitution defendants as victims of sexual violence, it is unlikely to portend less punitive treatment of other classes of defendants, even female defendants, who experience violence or other constraining circumstances. For this reason, the HTICs may not help to de-legitimize criminal punishment more generally or instill the view that anyone's criminal responsibility can be mitigated by evidence of coercion, trauma, or poor life circumstances. Indeed, despite its powerful rhetoric, the HTICs in many ways continue to treat prostitution defendants as ordinary misdemeanants even as it promises a paradigm shift premised on their sexual victimization.

\section{CONCLUSION}

Criminal law reforms designed to eradicate extreme violence, especially against vulnerable women and children, have long been publically popular, and vivid descriptions of horrific brutality at the hands of monstrous offenders have long fueled a penal appetite. In this sense, the rhetoric and philosophy of the anti-trafficking movement and the HTICs represents familiar territory. Understandable reprehension for extreme acts of violence and prurient fascination with deviant sex makes sex trafficking and forced prostitution a prime area for intense criminal law intervention.

However, this is no longer the "war on crime" era. Today, mass incarceration is a familiar term, court-reform projects are popular, and decarceration efforts abound. At this time, allegiance to tough-on-crime and broken windows ideology has waned. As such, we have argued that it is not at all inevitable or necessary-indeed, it is surprising-that law enforcement efforts against trafficking now involve targeting "ordinary" domestic prostitution, including support for arresting and prosecuting victims.

In this post-mass incarceration time, a new penology-today's penal welfare - may enable the entrenched institutions of criminal law to continue to function, despite an increasing crisis in public confidence. What do experts, policy makers, and stakeholders deeply embedded in the law do when faced with disenchantment in the enterprise? Oftentimes, they call for reform. Reforming select criminal courts by adding a welfare component seems like a win-win because the system can continue to do something about intolerable crimes (and be even tougher on certain criminal actors) and at the same time minimize the costs of criminal law through procedural improvements, decarceration efforts, and social services.

But as the HTIC story demonstrates, reform is not that simple. In encouraging alternatives to incarceration, one can easily lose sight of the burdens of penal management that do not involve jail. In embracing procedural justice, one might expend more effort convincing defendants 
that criminal management is fair than scrutinizing whether certain defendants should be managed by the criminal system at all. In lauding penal welfare, one might forget that the welfare comes with a human price tag involving demeaning and invasive arrests, criminal processing, and the threat of incarceration. And, in a neoliberal moment, many will point to the proliferation of penal welfare as obviating the need for welfare elsewhere. Moreover, court reform might tempt one to view criminal courts as the answer to, rather than a cause of, mass incarceration, even as they sustains arrests and prosecutions.

Ultimately, the HTICs maintain the illusion that criminal management of individuals, including prostitution defendants, is the answer to social dysfunction. As such, the HTICs, like criminal court interventions generally, insufficiently advance the social restructuring necessary to address the root causes of prostitution crimes. However, without receiving a much wider array of benefits-housing, employment, financial subsidies, childcare, healthcare-prostitution defendants find it challenging to take advantage of the court-mandated services assigned to them. Many HTIC stakeholders recognize as much. In turn, the criminal court's failure to solve the "problem" of commercial sex ironically maintains the need for problem-solving courts to address the extant social issues experienced by people arrested for prostitution.

Now that the United States is "turning the corner on mass incarceration," ${ }^{341}$ we suspect that reformers will increasingly propose alternative criminal law reform projects that, like the HTICs, purport to be win-wins. Here, we urge circumspection and hope that those concerned with the punitivity of U.S. society do not simply replace one form of penality with another, but engage the larger distributional consequences of criminal law reform-from-within. We see this Article as a part of that burgeoning conversation.

341. David Cole, Turning the Corner on Mass Incarceration?, 9 OHIO ST. J. CRIM. L. 27, 27 (2011) (asserting that several indicators suggest the U.S. incarceration rate recently began to decline). 